\title{
Weaponry and Military Equipment
}

Nubia's long history and links with Egypt and the Mediterranean world were significant to the development of metallurgy in Nubia from the Kerma to the post-Meroitic period (Drici 2016, 9). Nubian lands and mines had been important to Egypt since the Old Kingdom (Lebedev 2018, 277).

As pointed out by Mahmoud El-Tayeb, metal artefacts were not abundant in Early Makurian graves, in contrast to those discovered in the regions south of the Fifth Cataract or downstream of the Second. This could be attributable to looting. Metalwork recovered from excavations is usually in poor condition. Little is known about metallurgical knowledge in the Dongola Reach during this period. Archaeological evidence suggests that the main centre of metalworking was Meroe (Mahmoud El-Tayeb 2012, 81). Weapons discovered in the El-Zuma tumuli (blades, arrowheads, spears, and javelins) were made of iron. When exactly iron appeared still remains unclear. Excavations at Meroe have suggested that iron production may have begun there around the mid1st millennium BC in the late Napatan period (Tylecote 1982; Rehren 2001). The evidence of iron production at Meroe indicates that this production centre remained active till the post-Meroitic period. We do not know much about the trade and distribution of iron artefacts, or if Meroe played a significant role in the spread of iron production in Nubia (Humphris and Scheibner 2017; Humphris, Charlton et al. 2018). Political changes, pressure from Aksum, and tribal activity during the post-Meroitic period may have led to an increase in weapon production (Humphris and Scheibner 2017, 403; Humphris 2014, 127).

Military power is abundantly represented in postMeroitic graves. At El-Hobagi dozens of broad-bladed ceremonial spears, axes, swords, at least one bow, and several quivers full of arrows were buried together with the deceased (Lenoble 2018). While weaponry is relatively rare within the royal burials at Meroe, military equipment, if only in the form of bows and arrows, is increasingly common in later Meroitic male burials. In the postMeroitic period, a military element in male identities seems to have become very widespread, reflected in the ubiquity of arrowheads and archer's looses in graves of this period (Edwards 2004, 191-193). Elements of post-Merotic weaponry have frequently been found in tumulus tombs dating from the 4 th to the 6th centuries $\mathrm{AD}$, such as those at El-Hobagi, Ballana, Qustul, and Gabati (Lenoble 2018; Emery and Kirwan 1938; Edwards 1998, see also Figs 1 and 3 , at the end of this volume).

\section{Description of the Material}

The weapons discovered at the El-Zuma cemetery include bladed spearheads, leaf-shaped spearheads, javelins, pieces of an edged weapon, long combat knives, and a few smaller blades probably representing knives and at least one dagger. The author, Łukasz Zieliński, has divided this assemblage into the following categories and types:

- Pointed weapons/pole arms
a) Bladed spears
b) Spears
c) Javelins
- Edged weapons
- Ranged weapons
a) Arrowheads
b) Archer's looses/thumb rings

\subsection{Pointed Weapons/Pole Arms \\ 1.1.1 Bladed Spears}

[Figs 14.2-14.3] Descriptions of the bladed spears excavated at El-Zuma are based on the typology established by Emery and Kirwan for spears discovered at the royal cemeteries of Ballana and Qustul (Emery and Kirwan 1938, 221-223, Figs 83$85)$.

Only two bladed spearheads, both made of iron, were found at El-Zuma: one in tumulus 16 and the other in tumulus $4\left(\mathrm{Z}_{4} / 194\right)$. Both examples were incomplete and heavily corroded, and there were no preserved spear shafts. Their attribution to types is tentative. The example found in tumulus $16\left(\mathrm{Z} 16 / 4+\mathrm{Z}_{1} 6 / 14+\mathrm{Z} 16 / 15\right)$ [Cat. 1] is closest to Emery's type 2, where the spearhead is wide (up to $8 \mathrm{~cm}$ ) and long (up to $90 \mathrm{~cm}$ ) with cutting edges that run almost parallel. The one from grave 16 measures approximately $7.5 \mathrm{~cm}$ at its widest point, and has an extant length of $53.4 \mathrm{~cm}$, with the longitudinal mid-ribs running roughly symmetrically on both faces of the blade (it may originally have measured up to $80 \mathrm{~cm}$ in length). The ribs are $1.1-1.4 \mathrm{~cm}$ thick and about $1 \mathrm{~cm}$ high. The wings are approximately $0.6-0.7 \mathrm{~cm}$ thick around the ribs and measure $3 \mathrm{~cm}$ across at the widest point. The angle of the spear tip is not acute enough and amounts to about 70 degrees at 


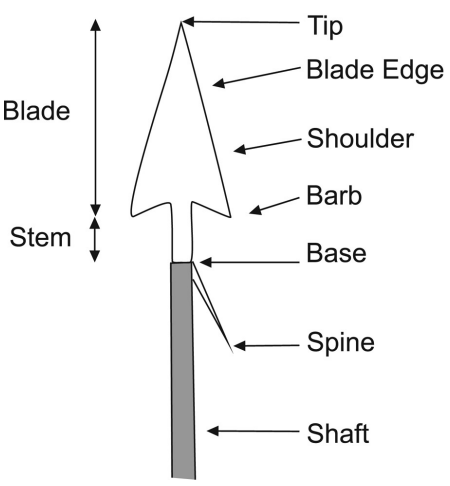

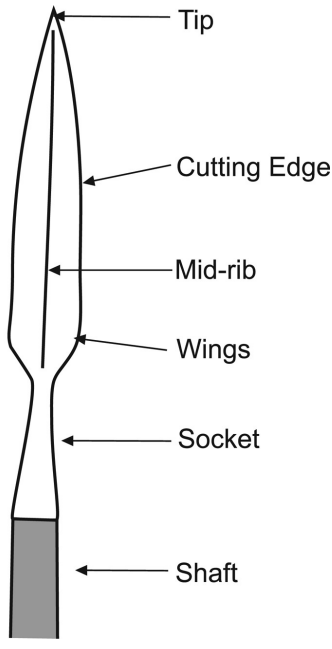

SKETCH 14.1

Arrows and spears terminology

DRAWN BY E. CZYŻEWSKA-ZALEWSKA the very beginning of the blade's curvature. The spearhead must originally have been very heavy judging from its size, but its original weight could not be estimated. A spear butt or shoe, like those found in Qustul (Emery and Kirwan 1938, 221-223), could have been used to counterbalance the weight of the head, but no such shoes were discovered at El-Zuma, probably because of the poor state of preservation of the spears. The shoe could also be driven into the ground to help support the weight of the weapon.

This spearhead consists of four large fragments and about ten smaller ones, which were identified and glued together (only the smaller ones). The large fragments have not been glued together because they offer an unprecedented opportunity to trace the layers of the spearhead in cross-section at different points along the tip. Thanks to this we have an insight into the technique that the blacksmith used to make the spearhead. Each wing consists of two layers of iron that were welded on the ribs to form a joint. Characteristic wedging of the layers formed in this way is visible in cross-section. This smithing technique was probably used because of the size of the weapon. The iron bloom obtained in a smelting furnace usually had to be subjected to further processing and worked into a relatively small ingot (bar). For an object as large as a bladed spear, at least two such ingots were needed, if not three (taking into account the core of the spear and the tang or socket made from the core). Technically, forging a swordshaped spearhead could be a problem for an inexpert blacksmith because of the stout rib on either face, which required forging at various angles and good visualization skills. The examples from El-Zuma were made with considerable deviations of the wings and ribs in relation to the axis of symmetry. This suggests that they were made by a blacksmith who must have had some experience of producing this type of weapon, but had not fully mastered the technique.

The bladed spear found in tumulus 16 was probably not very long. The examples found in tombs at Ballana and Qustul measured only $160-170 \mathrm{~cm}$ in length (Emery and Kirwan 1938, 222-223). We can assume that the hardest available wood was used for the shafts of pole arms. Meroitic and post-Meroitic spear shafts could have been made from tree species commonly referred to as ironwood, like Dalbergia or some of the African acacias, which were common in the Meroitic period and were also used in iron production (Zieliński 2011, 24-45; Gale et al. 2009; Humphris and Eichhorn 2019, 41-43). Tumulus 16 yielded a further three fragments of metalwork, which when pieced together turned out to be an iron sleeve [Cat. 2, Z16/37], with characteristic transverse ribs, typical of bladed spears. The glued fragment had an internal diameter of about $2.2-2.6 \mathrm{~cm}$ and a wall thickness of $0.2-$ $0.4 \mathrm{~cm}$. Wood impressions (shaft/pole remains) can be seen on the inner surface. This artefact was probably part of the spear described above.

The technical details described by Emery are worth noting. The spearheads that he found were embedded in the shaft with the help of a spike, which was an extension of the central rib. The sleeve or cylinder was made of a separate piece of metal, installed to the spearhead covering the tang inside. This sleeve was often decorated by transverse ribs. The sleeve additionally strengthened the connection with the shaft from the outside, making it very solid (Emery and Kirwan 1938, 222). Unfortunately, there is no extant base section of any of the bladed spearheads found at El-Zuma, only the small fragment of the sleeve mentioned above.

Fragments of another bladed spear [Cat. 3, Z4/194] were found in tumulus 4 . This object was very corroded 
and very poorly preserved, and its original size could not be estimated. It is smaller than the one from tumulus 16 , which can be deduced from the rib thickness of $1.4 \mathrm{~cm}$ and the wing thickness of around $0.4 \mathrm{~cm}$. The original width can be tentatively estimated at about $2.3-2.5 \mathrm{~cm}$. This would point to a different type of bladed spear, possibly attributable to Emery's type 4 (Emery and Kirwan 1938, 223, Fig. 85:5). This type of spear is narrower than type 2 and has an average length of about $60 \mathrm{~cm}$.

Damaged metal object $\mathrm{Z1o} / 36$ [Cat. 11] is probably a small ferrule from a bladed spear, found in tumulus 10. This item is clearly narrower at one end (maximum diameter $2.8 \mathrm{~cm}$, minimum $2.2 \mathrm{~cm}$ ). One edge is completely preserved. The side walls are $2 \mathrm{~mm}$ thick, and wood imprints are visible on their inner surface. There is also an extant rivet in the side wall. This was probably part of an iron shoe, which was designed to be driven into the ground. Its conical shape meant that if the shaft broke or the spearhead was lost, it could also be used as a spare point. The ferrule was attached to the shaft with a single rivet on one side, as observed among parallel finds from tombs at Qustul (Emery and Kirwan 1938, 222-223). It should be mentioned here that no recognizable fragments of a bladed spearhead were found in tumulus 10. Unfortunately, the tip of the ferrule is missing, but the fact that it measures almost $3 \mathrm{~cm}$ in diameter at the preserved end suggests that it was mounted on a fairly thick shaft, as recorded with other bladed spears.

Ribbed decoration similar to the examples presented above can be observed on another bladed spear from tomb 192A.7 at Qasr Ibrim. The blade of this specimen is $51 \mathrm{~cm}$ long and has a maximum width of $8.4 \mathrm{~cm}$; the total length of the spear was $2.35 \mathrm{~m}$ and it was dated to the Ballana culture, probably to the 3rd century AD (Mills 1982, 3637, Pl. LXXXVI:6). Spears found in grave An at Firka were

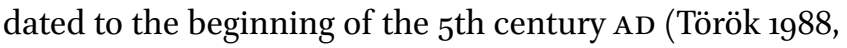
19o, Pl. 137). Examples excavated in tomb HBG III/1 at ElHobagi are $58 \mathrm{~cm}$ long with a maximum width of $6.8 \mathrm{~cm}$ and are dated to the 4th century AD (Lenoble 2018, 2122, 120-121, Fig. 65:197). More elaborate forms recorded in tombs at Ballana and Qustul were dated to the $3^{\text {th }}-5^{\text {th }}$ centuries AD (Emery and Kirwan 1938, 221-223, Fig. 83:2).

\subsubsection{Spears}

Leaf-shaped, iron spearheads can be distinguished among the weapons found at the El-Zuma cemetery. These spearheads have a broad, symmetrical blade, without ribs, and were reinforced by the use of a spindle-shaped crosssection. Four examples of leaf-shaped spearheads were found at the cemetery, all of them incomplete and heavily corroded. Three were found in tumulus 16 [Cat. 4, Z16/8.2,
Cat. 5, Z16/8.3, and Cat. 6, Z16/8.4] and one came from tumulus 24 [Cat. 7, Z24/32]. All four of them represent Emery's type 5 (Emery and Kirwan 1938, 5). Their thickness varies from $0.6 \mathrm{~cm}$ to $1.5 \mathrm{~cm}$; however, surface damage and considerable corrosion make it impossible to determine their true dimensions, although we can assume that they were originally about $0.9-1.3 \mathrm{~cm}$ thick. One wing of spearhead Z16/8.2 was reconstructed, revealing that it had a maximum width of $7 \mathrm{~cm}$. The base of the blade indicates that these spearheads were finished with a sleeve. Z16/8.2 is the best-preserved example of a leaf-shaped spearhead from El-Zuma, though its maximum length could not be reconstructed. An example of this type found by Emery in one of the Qustul tombs was $32 \mathrm{~cm}$ long including the tang (the blade was approximately $25 \mathrm{~cm}$ long), but this was a tanged spearhead rather than a socketed one like the specimen from tumulus 16 (Emery and Kirwan 1938, 223). It seems that the examples from El-Zuma are a little smaller. Z16/8.3 appears to be a little longer and narrower than Z16/8.2 (see reconstruction, Cat. 4). Unfortunately, due to its poor state of preservation, the maximum width and length could not be determined, and can only be estimated by analogy to examples of this type found at other sites.

The fragmentary preservation of these objects provides an opportunity to examine them in section and assess the smithing technique used in their production. It seems that the spearheads were made by forge-welding a core sandwiched between two outer layers of metal. Similar examples have been found at other post-Meroitic sites. The spearheads from El-Hobagi are dated to the 4th century AD (Lenoble 2018, 213-22O, 242-243, Figs 109-113), while those from Qustul are dated from the $3^{\text {rd }}$ to $5^{\text {th }}$ century AD (Emery and Kirwan 1938, 221-223, Fig. 85:5,6). Another example was found in a post-Meroitic tumulus at el-Misaktab, not far from Shendi and El-Hobagi (Abdelrahman, Sokary, and Bushara 2009, 109-110).

In terms of production technique, we can assume that the spearheads found in El-Zuma were forge-welded using two different types of iron [Fig. 14.1]. No specific metallographic studies were carried out on the El-Zuma material, hence we cannot confirm the use of two different types of iron. The only basis for this assumption is that this was the typical method used in forge-welding (evidenced by analogies from around the world). The tang had to be forged from the core layer. Leaf-shaped spearheads with a spindle-shaped cross-section did not require a high degree of skill from the blacksmith, as long as they were tanged rather than socketed. Forging a socket instead of a tang requires specialist tools and a greater level of proficiency. Forge-welding produced a harder blade and a core 


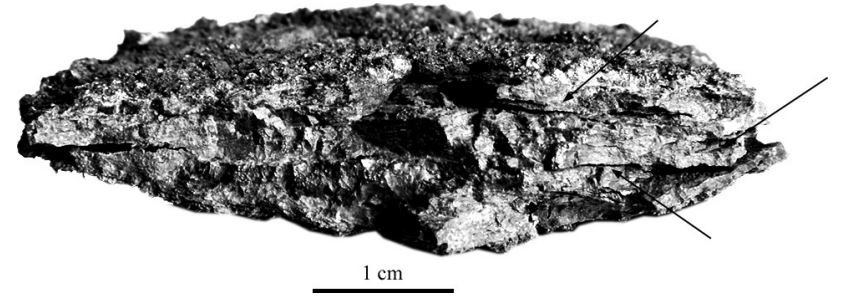

that was more resistant to compression and fracture. This also indicates that the person who made the spearheads was an experienced blacksmith.

Several theories about Meroitic and post-Meroitic iron production and smithing have been put forward by Peter L. Shinnie (Haaland and Shinnie 1985, 28-35; Zieliński 2011, 14-19) and Ronald F. Tylecote (1977). Both of them argued that Meroitic iron objects were of very good quality. Tylecote even carried out some metallographic research (microscopic metallographic analysis and the VickersRockwell hardness test), analysing one of the arrowheads from James Smith's collection (Tylecote 1977, 29-30; Zieliński 2011, 18-19). Shinnie suggests that bloomery design was the main reason for the production of good, highcarbon iron comparable to lower quality steel of today. A key factor was the use of as many as six tuyeres (nozzles) positioned very deep in the bloomery shaft, which provided additional oxygen-free heat (Haaland and Shinnie 1985, 28-35; Zieliński 2011, 17). Smithing furnaces were discovered at Meroe, which suggests that iron was not only produced in Meroe, but also worked into objects on-site (Haaland and Shinnie 1985, 28-35), even though no smithing tools were found in the vicinity.

\subsubsection{Javelins}

Four iron fragments of double-edged blades can be qualified as javelins. One [Cat. 8, Z16/6] was found in tumulus 16, two [Cat. 9, Z1o/35, and Cat. 11, Z1o/36] came from tumulus 10, and Z11/32 [Cat. 10] was discovered in tumulus 11. All of these fragments were found corroded and in a poor state of preservation.

The extant blade of $\mathrm{Z11} / 3^{2}$ is $9.4 \mathrm{~cm}$ long (its tip is missing) and $2 \mathrm{~cm}$ wide, with a rounded tang measuring approximately $0.5 \mathrm{~cm} \times 0.4 \mathrm{~cm}$. This object is a doubleedged leaf-shaped blade fragment that is spindle-shaped in cross-section. This javelin retains a small part of the tang, which has wood imprints on it (evidence of the shaft). The size of this imprint shows that the shaft was only $0.8 \mathrm{~cm}$ in diameter, although it could have been wider further along its length (the shaft may have tapered at one end).

Double-edged blade fragment $\mathrm{Z10} / 35$ is $4 \mathrm{~cm}$ long and $1.5 \mathrm{~cm}$ wide; it was forge-welded (3-layers) and has
FIGURE 14.1

Layer-forging technique, layers visible in cross-section ( $\mathrm{Z16} / 8.3)$ PHOTO BY A. KAMROWSKI

a spindle-shaped cross-section similar to Z11/32. The two fragments catalogued as $\mathrm{Z}_{10} / 36$ are part of a forged iron ferrule, probably from the same artefact as $\mathrm{Z1o} / 35$. Both were found in the same place in the burial chamber of tumulus 10, but it was not possible to reconstruct the whole artefact.

Javelin $\mathrm{Z} 16 / 6$ has a preserved length of $7.8 \mathrm{~cm}$ and measures $2.3 \mathrm{~cm}$ in width, with a thickness of approximately $0.4^{-0.5} \mathrm{~cm}$. Also made of forge-welded iron, with a core and outer layers, this fragment represents an elongated variant of a two-edged, leaf-shaped blade.

The javelins from El-Zuma are very narrow in relation to their length. The angle at the point is very acute, and usually around $23^{-25}$ degrees.

Because the javelins are broken it is possible to observe the construction of the blade in cross-section (core and two outer layers). The fact that the forge-welding technique was chosen for such a small blade is not attributable to the insufficient size of the iron ingots. It is more likely that it was used so that high- and low-carbon steel could be combined to produce a stronger blade. It seems that this technique was used for all major blades found at El-Zuma, namely spears, javelins, and knives. Unfortunately, due to their state of preservation (no extant core), it was impossible to confirm this through metallographic analysis. The production of javelin tips requires a smaller amount of force from the blacksmith and slightly higher precision than in the case of spearheads. Forging a tip with a spindle-shaped cross-section is relatively easy for a reasonably experienced blacksmith. Forging a tip with a central rib running symmetrically the length of each face requires additional focus. Perhaps that is why the blacksmith who made the $\mathrm{Z16} / 6$ javelin decided to forge a midrib on one side only, which makes the task much easier. It is evident that despite some skills in the selection of raw materials and technology, he had not mastered the art of forming mid-ribs symmetrically on both sides.

$\mathrm{Z16/6}$ and $\mathrm{Z} 10 / 35$ have a similar width and thickness of about $0.5 \mathrm{~cm}$. Z11/32 and $\mathrm{Z} 10 / 35$ have a spindle-shaped cross-section, and the $\mathrm{Z} 16 / 6$ javelin is spindle-shaped on one side, while on the other it has a symmetrically formed mid-rib running the entire length of the preserved fragment. 
At El-Zuma, each of the javelins was found in a different grave; however, at El-Hobagi one grave chamber sometimes contained multiple javelins (Lenoble 2018, 21-22, 212, Fig. 106:215), and in the Meroitic cemetery at Karanog, dated to the 1 st- 5 th century AD, more than one javelin was also found in tomb G.254 (Woolley and Randall-MacIver 1910, 40-41, Pl. 34). In Qasr Ibrim tomb 101 at cemetery 193, featuring Ballana culture and Christian burials, yielded an item described as a javelin blade that was $7.5 \mathrm{~cm}$ long and $2.7 \mathrm{~cm}$ wide (Mills 1982, 47, 56, Pl. Lxxxvi: 7). Another example was discovered in tumulus 5 in El-Detti, at a site that is dated to the Early Makurian period (Zieliński 2016, 424). The examples found in El-Zuma are very elongated and lanceolate, just like the ones from El-Hobagi (Lenoble 2018, 21-22, 212, Fig. 106:215). The El-Zuma javelins do, however, differ from those found at the royal cemetery in Qustul, which have very fanciful shapes, with constrictions in the middle or additional barbs (Emery and Kirwan 1938, 221-223, Fig. 85).

\section{$1.2 \quad$ Edged Weapons}

[Fig. 14.4]

Iron knives and long combat knives were also found in El-Zuma. This assemblage comprises two long combat knives, three other knife fragments and one dagger. Tumulus 10 yielded one long combat knife [Cat. 13, $\mathrm{Z10} / 3 \mathrm{O}$ ] and fragments of two other knives [Cat. 14, $\mathrm{Z} 1 \mathrm{o} / 3^{2+} \mathrm{Z10} / 33+\mathrm{Z} 1 \mathrm{o} / 34$, and $\left.\mathrm{Z} 1 \mathrm{o} / 31\right]$. The second long combat knife [Cat. 12, Z16/8.1] was found in tumulus 16. One knife [Cat. 15, Z4/7.1] and fragments of a dagger [Cat. 16, $\left.\mathrm{Z}_{4} / 107\right]$ were discovered in tumulus 4 .

The long combat knives recorded at El-Zuma were found in very poor condition, so their original appearance could only be ascertained by comparison with betterpreserved specimens from other archaeological sites.

Long combat knife $\mathrm{Z10} / 30$ is represented by two fragments measuring $18.1 \mathrm{~cm}$ and $10.8 \mathrm{~cm}$ in length respectively. It is a single-edged knife with a blade approximately $1.6 \mathrm{~cm}$ thick and at least $4.1 \mathrm{~cm}$ wide. It was made of forgewelded iron (core and outer layers). The second of the long combat knives, Z16/8.1, survives in the form of a fragment that is $26 \mathrm{~cm}$ long with a maximum width of $3.8 \mathrm{~cm}$. It was also made of forge-welded iron (core and outer layers). The spine has a thickness of about $1.1 \mathrm{~cm}$. Both knives Z1o/3o and Z16/8.1 feature wood imprints (probably from a scabbard). Fragment Z10/45 found in tumulus 10, and Z16/36 from tumulus 16 , might be parts of such a scabbard (see Chapter 15, Cat. 3 , this volume).

Emery referred to these long combat knives as swords (Emery and Kirwan 1938, 219-221), but in the light of other excavations they should be recognized as knives. Knives of this type did not have either a hand guard or a pommel, which makes it even more unfounded to call them swords (Gradowski and Żygulski 1998, 3-4, 19-20, 55, 58; Żygulski 1998, 56-72, 74-144).

Like other weapons, these long combat knives were also forge-welded. At least three layers of iron (a core and two outer layers) were used. Forging a combat knife in such a configuration is much simpler for a blacksmith than forging a spear or a javelin. Blades of such knives do not have any shavings, a fuller or mid-rib, and the side surfaces are flat. The only complication for the blacksmith was the additional forging of the rounded spine. Perhaps this design allowed the blade to be grasped from this side without risk of injury. It is hard to imagine a situation during a fight where this feature would have been needed, but it may have been practical for work in the field. The handle could have been made by another specialist depending on the material used. So in fact not only a blacksmith would have been involved in the production process, but also potentially a tanner, carpenter, horn worker, or even a goldsmith.

The smaller knife from tumulus $10\left(\mathrm{Z} 10 / 3^{2}+\mathrm{Z} 10 / 33^{+}\right.$ $\mathrm{Z} 1 \mathrm{O} / 34)$, reassembled from several fragments, is $14.6 \mathrm{~cm}$ long with a thickness of $0.5 \mathrm{~cm}$. The blade is single-edged, forge-welded, and the spine is very thick ( $2.1 \mathrm{~cm}$ wide) and rounded, which could be a useful feature. There are traces of copper patina on the flat tang, which may be the remnants of a structural skeleton that held the scales of the knife handle in place. The tip does not survive, so we cannot determine its shape. Fragment $\mathrm{Z}_{4} / 7.1$, found in tumulus 4, could be a small sleeve fragment from a small knife. The sleeve has a diameter of $1.4 \mathrm{~cm}$. A flat piece of metal wedged inside it is part of the tang. Wood impressions from the handle have also been preserved on the inside. Traces of copper patina on the surface show that this sleeve was originally covered with copper. Knives with a hand guard of this form have been noted at other postMeroitic sites, including an example from Qustul (Emery and Kirwan 1938, 327) most probably dating from the 4th

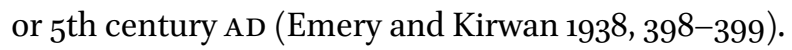

The combat knives from El-Zuma are similar in construction to a knife found in Missimina and dated to the 5th-6th century AD (Török 1988, 188). What could be determined from the fragments found at El-Zuma is that we are dealing with single-edged knives with a blade of triangular cross-section. The knives from both El-Zuma and Missimina have a rounded back. The handles of the examples found in El-Zuma are not preserved, but looking at those discovered in Qustul, and dated to the 4 th $-5^{\text {th }}$ century AD (Emery and Kirwan 1938, 219-221, 398-399), or Missimina (Török 1988, 188), we can assume that the knives were either whittle tanged (the knife had a nar- 
row tang that was inserted into a solid handle) or scale tanged (the tang was broad and flat, and the scales were riveted to it on either side to form a handle). The scales were made of wood or bone. Examples found among the ceremonial arms recorded at the royal cemetery in Qustul (Emery and Kirwan 1938, 219-221) were often decorated with silver plates and precious stones. Utilitarian knives had a bone handle with grooves for all five fingers, similar to that of a Roman gladius (Török 1988, 188). Examples excavated in tomb HBG III/1 at El-Hobagi, and dated to the 4 th century $\mathrm{AD}$, are of similar dimensions to those excavated at El-Zuma. One of them (no. 203) survives to a length of $26 \mathrm{~cm}$, with the blade measuring $25.1 \mathrm{~cm}$ long and $3.1 \mathrm{~cm}$ wide; the second one (204) has an extant length of $26.1 \mathrm{~cm}$, the surviving blade measuring $25.8 \mathrm{~cm}$ long and $3.7 \mathrm{~cm}$ wide (Lenoble 2018, 21-22, 126, Figs 70, 127).

Dagger $\mathrm{Z}_{4} / 107$ is $5.4 \mathrm{~cm}$ long, relatively narrow, and only $0.15 \mathrm{~cm}$ thick. It has a double-edged blade with a carefully worked bilateral groove hidden in a protruding midrib. Impressions and fragments of leather are preserved in the rust at the edge of the dagger. The greatest width of the preserved fragment is $3.4 \mathrm{~cm}$, while single-edged knives are usually narrower. On the basis of the surviving fragment, little can be said about the original dimensions of the dagger. Nevertheless, the angle of the cutting edge ( $c .35^{-40}$ degrees) indicates that the blade was that of a typical dagger.

The dagger blade is very thin and made from one piece of iron, probably without layering. Although the blade is forged from one piece of iron (not forged-welded or pattern-welded), it was skilfully forged. The mid-ribs and grooves run parallel to each other with very little deviation, and there are no traces of individual hammer strokes. The blade, although it is thin and sharp, is not twisted. It was very carefully made by a highly skilled blacksmith, using smaller tools. Interestingly, despite the fact that the blade is thin, corrosion has almost perfectly preserved its original shape, even though it was in direct contact with leather, which intensifies the effects of corrosion. This indicates that although the blade was not forgewelded, it may have been made of high-carbon iron. It is puzzling that there are few analogies of such daggers from other sites of this period (post-Meroitic). The El-Zuma dagger most closely resembles Berber knives (Burckhardt 1819, 297). Similar double-edged iron knives were also found at Abu Geili (Crawford and Addison 1951, 36-37, Fig. 9) in Funj graves 400/5 and 400/25.

Some very corroded pieces, described as unidentified fragments, such as Z26/91 (see Chapter 18.2, Cat. 22, this volume) and $\mathrm{Z}_{2} 6 / 10$ (not presented in the catalogue) may have come from knives, but are too damaged to make an accurate identification. They are large enough and have the right thickness, and are of sub-triangular crosssection. However, the delamination of these fragments, and sometimes the total lack of original surfaces, makes it impossible to assign them to a specific category.

\section{$1.3 \quad$ Ranged Weapons \\ 1.3.1 Arrowheads}

[Figs 14.5-14.9]

Arrowheads are the most numerous category of weapons found in the El-Zuma tombs. A typology of arrowheads based on their shape was presented by Łukasz Zieliński in his MA thesis (Zieliński 2011, 119-120) [Table 14.1]. Emery formulated typologies for spearheads and javelins, but not for arrowheads (Emery and Kirwan 1938, 221-223, Figs 83, 85). In fact, no typology has previously been devised for arrowheads from Nubia.

Arrowheads were the only items of archery equipment found in such quantities. Only five archer's rings were discovered at this site [Table 14.2]. No quivers were found, although groups of arrowheads fused together by corrosion bear leather impressions that could represent the remains of quivers.

Arrowheads came to light in tumuli 4, 10, 13, 16, 17, 19, 21,22 and 27. Usually, they were found in groups of at least a dozen pieces.

The following arrowhead types are represented in the El-Zuma assemblage:

- type 1 (single-barbed, triangular) [Cat. 17-36];

- type 1a (single-barbed, hooked) [Cat. 37-42];

- type 16 (single-barbed, leaf-shaped) [Cat. 43-54];

- type 6 (barbless, leaf-shaped) [Cat. 55-56];

- approximately 68 specimens could not be identified to type [Cat. 57-69].

A key feature of the arrowhead is its tip. The tips differ and we can distinguish three variants of tips within each type of arrowhead. The most common variant is represented by arrowheads of $4-5 \mathrm{~cm}$ in total length; the second, shorter variant consists of arrowheads with a total length of around $3 \mathrm{~cm}$ or less; and the third variant, which is the rarest, comprises elongated arrowheads, usually up to $7 \mathrm{~cm}$ in total length. Regardless of the type of tip, the usual width of the blade varies from $1 \mathrm{~cm}$ to $1.3 \mathrm{~cm}$. In barbed arrowheads, the barb protrudes a maximum of $0.5 \mathrm{~cm}$ (usually less) beyond the outline of the actual blade. The thickness of the blades is much more varied. The tips of types 1 and 1a are usually quite narrow, with a thickness of $0.2-0.3 \mathrm{~cm}$. On the other hand, type 6 and type $1 \mathrm{~b}$ arrowheads (both leaf-shaped types) are $0.3 \mathrm{~cm}$ or sometimes even $0.5 \mathrm{~cm}$ thick. This is attributable to the use of a slightly different production technique. Arrowheads that 
TABLE 14.1 Arrowhead typology established by Ł. Zieliński

TYPE Arrowhead type

Type 1 Single-barbed, triangular, asymmetrical, tanged (of various dimensions and with variously angled barb; noted at sites at the Fourth Cataract and Karanog)

Type 1a Single-barbed, hooked, asymmetrical, tanged (very long barb in the form of a half swallow-tail; noted at Karanog)

Type $1 \mathrm{~b} \quad$ Single-barbed, leaf-shaped, asymmetrical, tanged (barb protruding from base of blade, close to tang; noted at Karanog and El-Hobagi); in El-Hobagi arrowheads of this type had a toothed tang

Type 2 Double-barbed, triangular, symmetrical, socketed instead of tanged (noted at Karanog)

Type 2a Double-barbed, triangular, symmetrical, tanged (noted at El-Hobagi)

Type 3 Double-barbed, with forked point, symmetrical, tanged (very rare; noted at Karanog), probably poisoned

Type 4 Four-barbed, triangular, symmetrical, mid-rib, tanged (noted at Meroe), made of copper alloy

Type 5 Six-barbed, triangular, symmetrical, mid-rib, tanged (noted at Meroe), made of copper alloy

Type 6 Leaf-shaped, barbless, symmetrical, tanged (noted at Karanog and the Fourth Cataract)

Type 7 Open-work, barbless, leaf-shaped, symmetrical, tanged (incendiary—openwork head could be filled with oakum soaked in a flammable substance; noted at Karanog—complex openwork, and El-Hobagi—simple openwork)

Type 8 Needle-shaped with multiple barbs (mid-rib), asymmetrical, tanged (very rare, noted at Karanog)

Type 9 Needle-shaped, rounded in cross-section, tanged (probably anti-armour point; very rare, noted at Karanog)

are 0.3 and $0.2 \mathrm{~cm}$ thick were very heavily flattened by strong hammer blows, and required less raw material to manufacture because they were thinner but of the same width as other types. On such a flattened surface it was much easier to use a chisel or punch to create a barb. The arrowheads that are $0.5 \mathrm{~cm}$ thick were forged with lighter blows struck at different angles. Perhaps it is because this requires good access from all sides that it was mainly leafshaped tips that were forged in this fashion.

Twenty-five (or possibly 35$)^{1}$ examples of a singlebarbed, triangular arrowhead of type 1 were found in the El-Zuma tumuli [see Table 14.2]. Type 1 arrowhead Z16/26.2 [Cat. 31] was made using a relatively simple technique. This arrowhead has a slightly triangular shape and a single barb. It is spindle-shaped in cross-section (both faces are symmetrical) and was forged on both sides. Viewed edge-on, the tang and barb are in line with one another. The barb extends slightly at the top and its side surfaces coincide with the surfaces of the tang and the blade. This means that all surfaces were shaped simultaneously with individual hammer blows. The tang itself is rectangular in cross-section. The smithing technique used to produce this projectile point was simple and required

1 Two quantities are given for arrowheads of types 1 and 1a because some of them survive in such a condition that it is difficult to determine which of these two types they represent, although they can conclusively be attributed to one of the two rather than, for example, to type $\mathrm{ib}$ or type 6 . little effort. It was the most commonly used technique for making post-Meroitic arrowheads.

Eleven potential examples of single-barbed, hooked arrowheads of type 1a (one of them positively identified) were recovered from the El-Zuma tumuli [see Table 14.2]. Normally, type 1a (hooked) arrowheads had asymmetrical, single-barbed tips. The edge of the blade led from the point to the edge of the barb without deviating or differing in thickness. The barb resembled half of a long, narrow and arched swallow's tail, which is why it is referred to as hooked. Most arrowheads of this type are flat or slightly spindle-shaped in cross-section and are $2-3 \mathrm{~mm}$ thick. This demonstrates that the tips were forged on both sides on the flat surface of an anvil, without the use of additional tools. A chisel was used to create the barb. The barb can be very long (up to $2 \mathrm{~cm}$ ) compared to other types of tips, but it does not project very far beyond the main part of the blade. The blade itself is relatively short and terminates in a tang. The blade tip of arrowhead Z16/26.3 [Cat. 32] is approximately $1 \mathrm{~mm}$ thick and has a flat surface with sharp edges on both sides. The barb was shaped when the blade was hot and malleable. Traces of the blacksmith's work are visible in the form of furrows left by the hammer strokes on the barb surface. Rectangular strike marks from a chisel can also be seen at the base of the barb. On both sides, there are ribs that are slightly asymmetrical in relation to each other, and semi-circular in crosssection (at this point the tip is $4 \mathrm{~mm}$ thick). The only logical explanation for this construction is that a small blade (probably made of high-carbon, hardened steel) was 
TABLE 14.2 Quantitative list of arrowheads and archer's rings found in the El-Zuma tumuli

Tumulus no. Type of tumulus

\section{Arrowheads}

Archer's rings

type 2 type 4 type 8

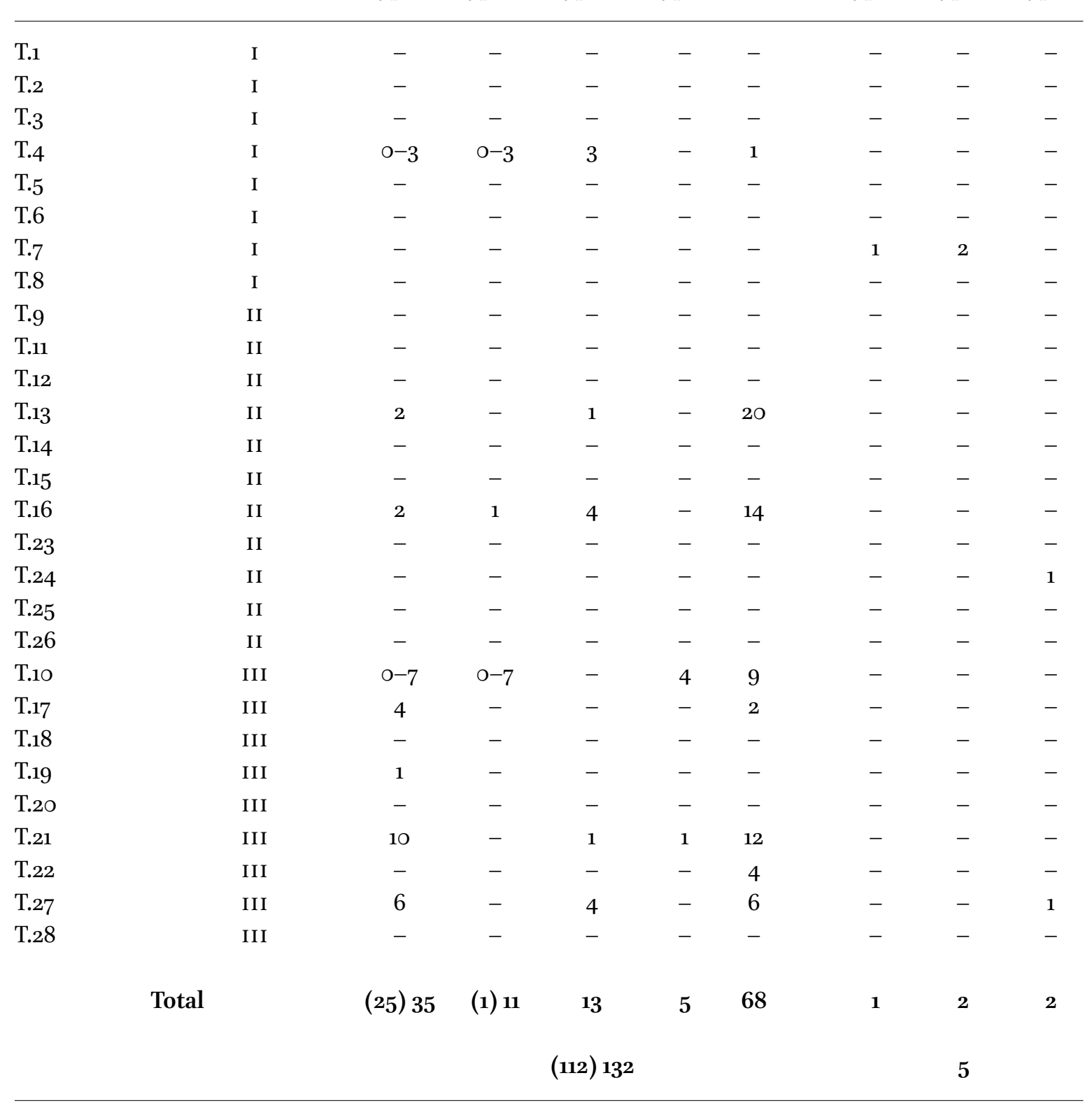

PRODUCED BY Ł. ZIELIŃSKI, E. CZYŻEWSKA-ZALEWSKA

actually wedged into a kind of fork formed by ribs that were hot-worked and later not tempered. This is a very unusual technique that is not noted in other finds of the period.

Thirteen examples of single-barbed, leaf-shaped arrowheads of type $1 \mathrm{~b}$ were found in the graves at El-Zuma. This type was usually made by the same technique as type 1a. It is typically flat or spindle-shaped in cross-section, o.2$0.5 \mathrm{~cm}$ thick, and was forged on both sides on a flat anvil surface. The barb usually measures less than $1 \mathrm{~cm}$. The arrowhead itself can be very long $(7 \mathrm{~cm}$ with the tang), but most often measures around $5 \mathrm{~cm}$ in length.

$\mathrm{Z16/26.1} \mathrm{[Cat.} \mathrm{46]} \mathrm{is} \mathrm{an} \mathrm{unusual} \mathrm{example} \mathrm{of} \mathrm{this} \mathrm{type.}$ The blade is perfectly flat on one side. This flat surface, which was placed on the anvil during the smith's work, was only subjected to grinding. The surface on the other side is slightly slanted, measuring about $1 \mathrm{~mm}$ at its thickest point. All protruding elements of this arrowhead, such as the tang and barb, were made on this side. The barb tapers evenly all the way up and has a square cross-section 
of approximately $0.2 \mathrm{~cm}$ at the base. This arrangement makes the side surfaces of the tip not symmetrical with each other, and the tang is rounded in cross-section, which would have required additional smithing work.

Only five barbless, leaf-shaped arrowheads of type 6 were found. Their tips do not have any barbs, they are symmetrical and usually of a very elongated leaf shape. Arrowheads of this type are less frequent in El-Zuma than barbed arrowheads. In this material catalogue, only five examples are presented: arrowhead Z1o/37 [Cat. 55], three arrowheads joined together Z1o/47 [Cat. 56] and artefact Z21/11.10 [Cat. 28] comprising an arrowhead of type 6 fused with an arrowhead of type 1. Barbless, leaf-shaped arrowheads have a total length of approximately $5 \mathrm{~cm}$, a width of 1.1-1.2 cm and a thickness of approximately 0.4$0.5 \mathrm{~cm}$. Fragments of around 20 arrowheads were found in tumulus 10, but only four of them were leaf-shaped.

The most varied weapons assemblage, including arrowheads, was found in tumulus 16 . The shaft and the main burial chamber (no. 1) yielded a combined total of at least 21 arrowheads. Seven of them are almost complete, and approximately 20 are preserved fragmentarily; the minimum number of arrowheads was estimated at 21 and the maximum number at 29. We can speculate that a quiver of arrows may have been buried in tumulus 16, but no traces of leather were found in this tomb.

The arrowheads recovered from tumulus 16 are examples of types $1,1 \mathrm{a}$ and $\mathrm{lb}$, and represent three smithing techniques. If there actually was one quiver in tumulus 16 , this raises questions about whether the arrowheads came from one manufacturer, and also about their functions and chronology in relation to each other. Arrows break and are lost during usage. This means that at some point the original supply has to be replenished, most often ad hoc with ones acquired from a local blacksmith. Perhaps the arrowheads from tumulus 16 reflect this very scenario.

The arrowheads discovered in the El-Zuma tumuli are typical of those seen at many post-Meroitic sites. The single-barbed arrowhead featured in Meroitic tradition and continued to be used during the post-Meroitic period. A type $\mathrm{ib}$ arrowhead was found in a Meroitic grave at elMisaktab (Abdelrahman, Sokary, and Bushara 2009, 109110, Pl. 3). Arrowheads of types $1,1 \mathrm{a}, 1 \mathrm{~b}$ and 6 were found at Karanog and dated to the 1st-5th century AD (Woolley and Randall-MacIver 1910, 66, Pl. 34).

Examples of arrowheads of types $1 \mathrm{a}, \mathrm{lb}$ and 6 were found in the Early Makurian tumuli at El-Detti (Zieliński $2016,422-424)$. Iron arrowheads of type 1a or 1 were discovered at Mikaisir Fortress and dated to the post-Meroitic period, AD 392-538 (Rees, Lahitte, and Näser 2015, 180-181, Fig. 18). Large numbers of different types of iron arrow- heads, either in the form of single specimens or joined in quivers, were found at El-Hobagi III, VI and dated to the 4th century AD (Lenoble 2018, 105-114, 203-208). Iron arrowheads of type 1 or 1a were discovered at the postMeroitic cemetery of El-Sadda 1 (Osypiński 2007, 360), while arrowheads of types $1 \mathrm{~b}$ and 6 were discovered in Gebel Adda (Grzymski 2010). A single-barbed arrowhead was found at the Hagar El-Beida 2 cemetery, dated to the Late Meroitic and post-Meroitic period (Longa 2007, 377378, Fig. 4). Single-barbed iron arrowheads from cemetery 193, containing Ballana and Qustul culture burials, were found at Qasr Ibrim (Mills 1982, 48, Pl. LV: 32.2). Iron arrowheads were found in post-Meroitic tombs at the Gabati cemetery (Edwards 1998, 127, Fig. 5.12). In Akkad, postMeroitic grave 29 yielded six very corroded iron arrowheads of type 1 or 1a with a maximum length of $0.6 \mathrm{~cm}$ (Faroug, Saeed, and Tsakos 2007, 100-101, Pl. XXXIX).

\subsubsection{Archer's Looses/Thumb Rings}

Five archer's rings were found at El-Zuma [see Fig. 14.10]: Z27/6 [Cat. 73] was recovered from tumulus 27, Z24/6 [Cat. 72] was found in tumulus 24, and three further examples $\mathrm{Z}_{7} / 2$ [Cat. 70], Z7/3 [Cat. 69] and $\mathrm{Z}_{7 / 4}$ [Cat. 71] came from tumulus 7 . Ring $\mathrm{Z}_{7} / 3$ represents type $2, \mathrm{Z}_{7} / 2$ and $Z_{7} / 4$ represent type 4 and rings $Z_{24} / 6$ and $Z_{27} / 6$ can be ascribed to type 8 of Emery's typology (Emery and Kirwan 1938, 233-234, Fig. 88).

Type 2 rings are the longest (see Catalogue), and the examples from El-Zuma have concave side surfaces and sharp edges (flat top and base). Type 4 rings are smaller than type 2 and have flat side surfaces, but are sharp-edged (flat top and base). Type 8 rings are not very long, with flat side surfaces and a rounded top and base (see Catalogue).

The archer's looses ascribed to type $8\left(\mathrm{Z}_{24} / 6, \mathrm{Z}_{27} / 6\right)$ were made of hard rocks (diorite and granite) and had well-polished surfaces. Straight-sided, similar in shape and dimensions, $\mathrm{Z}_{24} / 6$ is $3.1 \mathrm{~cm}$ high with a width of $3.9 \mathrm{~cm}$ at the top and $5 \mathrm{~cm}$ at the base. Z27/6 is $3.27 \mathrm{~cm}$ high and measures $3.7 \mathrm{~cm}$ at the top and $5.1 \mathrm{~cm}$ at the base. The thumb holes of the rings were smoothed and polished, and their usage is indicated by the fact that the internal surface has acquired a characteristic sheen from contact with the hand.

Artefact $\mathrm{Z}_{7} / 3$, a type 2 ring with slightly concave sides, and straight-sided $Z_{7} / 2$ and $Z_{7} / 4$, representing type 4, were made of softer and more porous rocks (feldspathic sandstone and probably porphyry). Both types are longer than type 8 rings. The type 2 ring $Z_{7} / 3$ is $4.7 \mathrm{~cm}$ high and $5 \mathrm{~cm}$ wide at the base. The type 4 rings $\mathrm{Z}_{7} / 2$ and $\mathrm{Z}_{7} / 4$ are a little smaller, with a height of $4.2-4.4 \mathrm{~cm}$ and a width of $4.6-$ $4.8 \mathrm{~cm}$ at the base. These three rings feature longitudinal 
grooves evidencing sawing inside the thumb hole. Presumably, they were used very little or not at all.

We can surmise that the short rings had been used before they were deposited in the grave, while the long ones had perhaps never been used. Evidence to support this theory was provided by microscopic examination and tests using a wooden replica of a ring with sharp edges (Zieliński 2015, 791-801). During microscopic examination, longitudinal saw marks were noted inside the long rings. The saw marks on the short rings are smaller, and obliterated by further grinding and polishing of the surface. This means that the processing of the long rings was never completed. Consequently, the finger hole was left unfinished and therefore unusable.

Another reason for believing that the long rings were never used is that they may have blocked the thumb joint. A ring could be torn from the finger by a taut bowstring. Experiments with a replica ring with sharp edges also showed that using a sharp-edged ring could result in abrasion and damage to the bowstring. This could lead to accidents that were very dangerous for the archer (including loss of an eye). Hence, it is clear that only the short and smooth-edged rings were fully usable. Detailed information about how these rings were used in Nubian archery was published by Łukasz Zieliński (2015).

Ring Z7/4 was decorated with a cross motif. Similar decoration was noted on the bottles discovered in tumulus 12, which had different forms of crosses scratched on their surface (see Volume II, Chapter 3.3.5). No similar decoration has been recorded on the archer's looses found at other sites.

None of the rings was found on a finger bone (most of them were recovered from the fill of shafts or tunnels). Examples from tumulus 7 were discovered in the tunnel, $\mathrm{Z} 26 / 6$ was found in the shaft and no arrowheads were found with the rings. Only Z27/6 was found in the burial chamber, close to the skull, and was accompanied by at least 16 arrowheads.

A straight-sided thumb ring was recorded in a Meroitic grave in Wadi Muqaddam (Smith 1998, 49, Pl. 3). An example of the granite thumb rings of type IC of Hayes' typology was found in a Meroitic grave at el-Misaktab (Abdelrahman, Sokary, and Buchara 2009, 109-110, Pl. 3). In a Late Meroitic period grave at Botri, a granite archer's loose was found in situ on the thumb bone of the left hand of a female (Bashir 2007, 95-96, Pl. 3).

Archer's looses similar to Z24/6 and Z27/6, and of comparable dimensions, discovered at Mikaisir Fortress were dated to the post-Meroitic period, AD 392- 538 (Rees, Lahitte, and Näser 2015, 181, 187-189, Figs 14, 22). Examples from Shemkhiya were dated to the Late Meroitic or post-
Meroitic period (Żurawski 2010, 373-373, Fig. 4). Thumb rings of all three types were discovered at Gebel Adda and dated to the Meroitic to post-Meroitic period (Grzymski 2010). In Qasr Ibrim, archer's looses made of porphyritic rock were discovered at cemeteries 192A and 193, dated to the Late Meroitic and post-Meroitic periods (Mills 1982, 37, 61, Pls XL:7.4, LXVI:135.1). In post-Meroitic grave 21 at Akkad, four stone archer's rings were found, one of them on a thumb bone (Faroug, Saeed, and Tsakos 2007, 100101, Pl. XXXIX). A stone ring was found in post-Meroitic cemetery DS2 at Mansourkuti, together with an iron ring and arrows (Bashir 2014, 158-159, Pl. 7). A tall alabaster ring $(5 \mathrm{~cm}$ high) was found in tomb 201 at Sesebi and dated to the post-Meroitic period (Edwards 1994, 164, 170, Fig. 6:329). In Ballana and Qustul numerous thumb rings of types 2, 4 and 8 were found together with other weapons, such as arrows, inside metal bowls (Emery and Kirwan 1938, 233-248, Pl. 53).

\section{Catalogue}

\subsection{Legend to the Catalogues}

The catalogue sections of chapters: 14 (weapons), 15 (belt elements), 17 (miscellaneous), and 18 (funerary equipment) present the most interesting artefacts of the metalwork assemblage, highlighting differences in their shapes, sizes, and states of preservation. Most artefacts are preserved fragmentarily. Some inventory numbers cover a group of multiple fragments. Details of the most interesting of these fragments can be found in the description of the object, which also includes information about how many fragments there are in the discussed group. Photographs are provided to give a better idea about the state of preservation of groups of objects recorded under a single inventory number.

$\begin{array}{ll}\text { Dimensions: } \\ \mathrm{L}=\text { length } \\ \mathrm{W}=\text { width } \\ \mathrm{Th}= & \text { thickness } \\ \mathrm{D}= & \text { diameter }\end{array}$

Arrowheads and archer's rings are presented by types.

\section{$2.2 \quad$ Bladed Spears and Spears}

Cat. 1

Bladed spear reassembled from several smaller fragments (incomplete spearhead)

Inv. no.: $\mathrm{Z16} / 4+\mathrm{Z16} / 14+\mathrm{Z} 16 / 15$

Context data: Tumulus 16, shaft, near damaged blocking wall of chamber 1 
Dimensions: $\mathrm{L}=53.4 \mathrm{~cm}, \mathrm{~W}=7.5 \mathrm{~cm}$ (wings approximately $3 \mathrm{~cm}$, ribs $1.1-1.3 \mathrm{~cm}$ ), $\mathrm{Th}=0.6-0.7 \mathrm{~cm}$ (wings around the ribs), $\mathrm{Th}=2.1 \mathrm{~cm}$ (rib)

Material and technique: Forge-welded iron on both sides (one wing forged from two lobes of iron welded together on ribs)

Description: Bladed spearhead, with mid-rib slightly offcentre on both faces, heavily corroded and cracked (pieced together from 10 fragments), Emery type 2.

References: Zieliński 2014, 380-382

Cat. 2

Sleeve, pieced together from three smaller fragments Inv. no.: Z16/37

Context data: Tumulus 16, chamber 1, near vessel no. 2

Dimensions: Inner $\mathrm{D}=c .2 .2-2.4 \mathrm{~cm}$, outer $\mathrm{D}=c .2 .6-2.8 \mathrm{~cm}$, wall $\mathrm{Th}=0.2 \mathrm{~cm}$

Material and technique: Forged iron

Description: Part of transversely ribbed (corrugated sheet in section) iron sleeve reassembled from three smaller fragments, with more or less consistent cross-section.

Notes: The sleeve was found relatively close to a bladed spearhead. Bladed spear finds from other sites suggest that sleeves decorated with transverse striations were used exclusively on spearheads of this type. Therefore, it seems reasonable to recognize sleeve $\mathrm{Z16/37}$ as a part of a bladed spearhead.

References: Zieliński 2014, 380

Cat. 3

Bladed spear (incomplete spearhead)

Inv. no.: $\mathrm{Z} 4 / 194$

Context data: Tumulus 4, E tunnel

Dimensions: $\mathrm{W}=2 \mathrm{~cm}$ (original $\mathrm{W}=2.5 \mathrm{~cm}$ ), $\mathrm{Th}=0.4 \mathrm{~cm}$ (wings around the ribs), $\mathrm{Th}=1.1 \mathrm{~cm}$ (rib)

Material and technique: Forge-welded iron on both sides (one wing forged from two lobes of iron welded together on ribs)

Description: Bladed spearhead, with mid-rib slightly offcentre on both faces, heavily corroded and cracked (pieced together from several fragments), Emery type 5 .

Z16/8 - group of eight spear fragments

Context data: Tumulus 16, shaft, near damaged blocking wall of chamber 1

Material and technique: Forge-welded iron (core and outer layers)

References: Zieliński 2014, 380-382

(Cat. 4-6, selected fragments)

\section{Cat. 4}

Spear, spearhead fragment

Inv. no.: Z16/8.2

Dimensions: $6.2 \mathrm{~cm} \times 7 \mathrm{~cm}, \mathrm{Th}=1.2-1.5 \mathrm{~cm}$ on the axis of symmetry of the tip, $\mathrm{D}=1.7 \mathrm{~cm} \times 1.5 \mathrm{~cm}$ (socket)

Description: Small leaf-shaped spearhead fragment (Emery type 5), heavily corroded with broken point and socket. Wings asymmetrical. Part of one wing glued (originally among fragments catalogued as $\mathrm{Z16} / 17$ ). Blade spindle-shaped in cross-section.

\section{Cat. 5}

Spear, spearhead fragment

Inv. no.: Z16/8.3

Dimensions: $5.4 \mathrm{~cm} \times 5.5 \mathrm{~cm}$, spearhead Th $=0.9-1.2 \mathrm{~cm}$ along midline of blade

Description: Small leaf-shaped spearhead fragment, heavily corroded with point and base missing (only middle part of blade survives with fragmentary cutting edges). Wings asymmetrical. Blade spindle-shaped in crosssection, Emery type 5 .

\section{Cat. 6}

Spear, spearhead fragment

Inv. no.: Z16/8.4

Dimensions: $6 \mathrm{~cm} \times 5.5 \mathrm{~cm}$, spearhead $\mathrm{Th}=0.9 \mathrm{~cm}$ along midline of blade

Description: Small leaf-shaped spearhead fragment, heavily corroded with point and base missing (only middle part of blade survives without cutting edges). Blade spindle-shaped in cross-section, Emery type 5 .

Cat. 7

Spear, spearhead fragment

Inv. no.: $\mathrm{Z24} / \mathbf{3 2}^{2}$

Context data: Tumulus 24, chamber 1, SE part, next to bones and cluster of metal objects

Dimensions: $\mathrm{L}=6.2 \mathrm{~cm}, \mathrm{~W}=3.1 \mathrm{~cm}, \mathrm{Th}=0.6 \mathrm{~cm}$ (original $\mathrm{Th}=0.8 \mathrm{~cm})$

Material and technique: Forge-welded iron (core and outer layers)

Description: Leaf-shaped spearhead fragment (probably elongated variant), heavily corroded with point and base missing (only middle part of blade survives). Blade spindle-shaped in cross-section.

\subsection{Javelins}

\section{Cat. 8}

Javelin blade, chipped point fragment

Inv. no.: $\mathbf{Z 1 6 / 6}$

Context data: Tumulus 16, shaft, near damaged blocking wall of chamber 1 


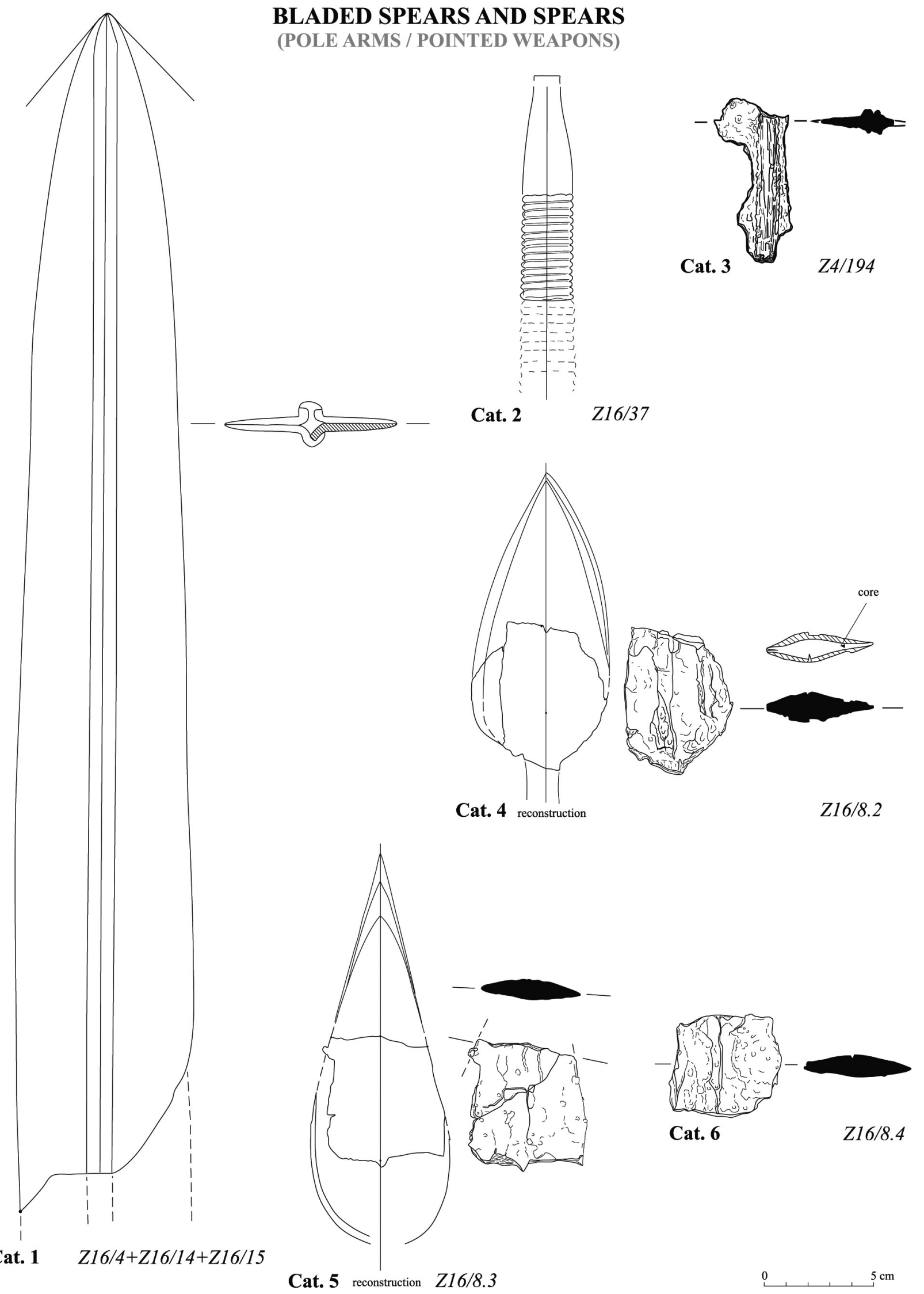

FIGURE 14.2 Pole arms/pointed weapons, bladed spears

$\mathrm{Z16} / 4+\mathrm{Z1} 6 / 7+\mathrm{Z1} 6 / 14+\mathrm{Z1} 6 / 15, \mathrm{Z16} / 37, \mathrm{Z16} / 8.2, \mathrm{Z16} / 8.3, \mathrm{Z16} / 8.4$ DRAWN BY Ł. ZIELIŃSKI, DIGITISED BY E. CZYŻEWSKA-ZALEWSKA; Z4/194 DRAWN AND DIGITISED BY Ł. ZIELIŃSKI 


\section{BLADED SPEARS AND SPEARS}

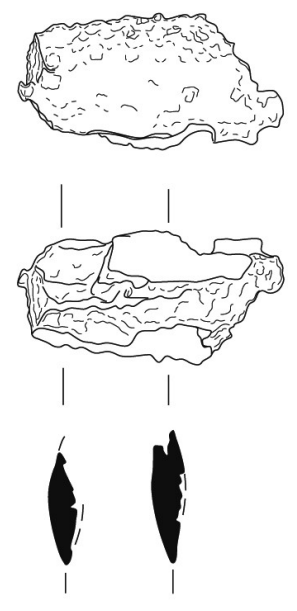

Cat. 7

$Z 24 / 32$

\section{JAVELINS}

(POLE ARMS / POINTED WEAPONS)

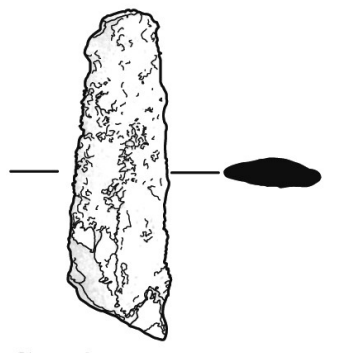

Cat. 8

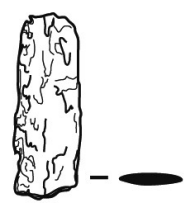

Cat. $9 \quad Z 10 / 35$

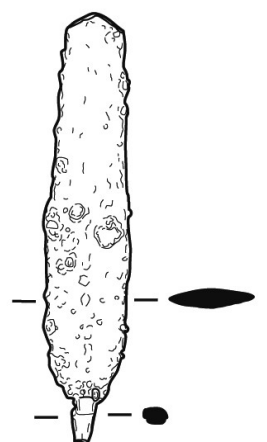

$Z 11 / 32$

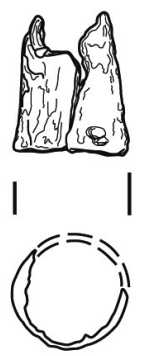

Cat. $11 \quad Z 10 / 36$
Cat. 10 $5 \mathrm{~cm}$

FIGURE 14.3 Pole arms/pointed weapons, bladed spears and javelins Z24/32 DRAWN BY Ł. ZIELIŃSKI, DIGITISED BY E. CZYŻEWSKA-ZALEWSKA; Z16/6 DRAWN BY K. JUSZCZYK, DIGITISED BY U. IWASZCZUK; Z1O/35, Z11/32, Z1O/36 DRAWN BY A. BŁASZCZYK, DIGITISED BY Ł. ZIELIŃSKI

Dimensions: $\mathrm{L}=7.8 \mathrm{~cm}, \max \mathrm{W}=2.3 \mathrm{~cm}, \mathrm{Th}=0.4-0.5 \mathrm{~cm}$ along midline of blade

Material and technique: Forge-welded iron (core and outer layers)

Description: Two-edged, leaf-shaped blade fragment. The mid-rib of rhomboid cross-section and the small dimensions of the blade suggest that this is actually a fragment of javelin head. The rib is still visible on one face, along the midline of the blade. On the other side no rib is visible (perhaps due to the severe corrosion of all surfaces of the blade).

References: Zieliński 2014, 382
Cat. 9

Double-edged blade (probable javelin head)

Inv. no.: $\mathrm{Z1O} / 35$

Context data: Burial chamber

Dimensions: $\mathrm{L}=4 \mathrm{~cm}, \mathrm{~W}=1.5 \mathrm{~cm}, \mathrm{Th}=0.3-0.5 \mathrm{~cm}$, shaft (evidenced by wood grain impression on tang) $0.8 \mathrm{~cm}$ $\times 0.5 \mathrm{~cm}$

Material and technique: Forge-welded iron

Description: Double-edged blade (probable javelin), spindle-shaped cross-section, forge-welded (3 layers). 
Cat. 10

Javelin head with broken tang and point

Inv. no.: Z11/32

Context data: Tumulus 11, chamber $1, \mathrm{~W}$ part

Dimensions: $\mathrm{L}=9.4 \mathrm{~cm}, \mathrm{~W}=2 \mathrm{~cm}, \mathrm{Th}=0.5 \mathrm{~cm}$, tang (rounded) $0.5 \mathrm{~cm} \times 0.4 \mathrm{~cm}$

Material and technique: Forged iron

Description: Heavily corroded javelin head, two-edged, leaf-shaped blade fragment. Spindle-shaped crosssection.

Cat. 11

Iron ferrule fragments (probably the same object as $\mathrm{Z1O} / 35)$

Inv. no.: $\mathrm{Z1o} / \mathbf{3} 6$

Context data: Burial chamber

Dimensions: $\mathrm{D}=2.8-2.2 \mathrm{~cm}, \mathrm{Th}=0.2 \mathrm{~cm}$

Material and technique: Forged iron

Description: Two iron ferrule fragments (heavily corroded and broken) with traces of wood inside.

\section{$2.4 \quad$ Edged Weapons}

Cat. 12

Long combat knife reassembled from several smaller fragments (incomplete blade)

Inv. no.: Z16/8.1

Context data: Tumulus 16, shaft, near damaged blocking wall of chamber 1

Dimensions: $\mathrm{L}=26 \mathrm{~cm}$ (after gluing), $\max \mathrm{W}=3.8 \mathrm{~cm}$ (without original cutting edge), original $\mathrm{Th}=c$. $1-$ $1.1 \mathrm{~cm}$

Material and technique: Forge-welded iron (core and outer layers)

Description: Single-edged blade with triangular crosssection and slightly rounded back edge (original rounded back edge survives on small fragment of blade). Original cutting edge does not survive. Blade severely cracked, corroded and in many places delaminated. Wood grain impressions visible on one heavily delaminated and thick fragment of rust coating lateral surface. Similar impressions visible on back edge surface (remains of scabbard).

References: Zieliński 2014, 382

\section{Cat. 13}

Long combat knife, reassembled from several smaller fragments (incomplete blade)

Inv. no.: $\mathrm{Z} 10 / 30$

Context data: Tumulus 10, burial chamber

Dimensions: Fragment a: $\mathrm{L}=18.1 \mathrm{~cm}$, fragment b: $\mathrm{L}=10.8 \mathrm{~cm}$ (after gluing); $\max \mathrm{W}=4.1 \mathrm{~cm}$, original $\mathrm{Th}=c .1 .6 \mathrm{~cm}$
Material and technique: Forge-welded iron (core and outer layers)

Description: Single-edged blade with triangular crosssection and slightly rounded back edge (original rounded back edge survives on small fragment of blade). Original cutting edge does not survive. Blade severely cracked, corroded and in many places delaminated. Wood grain impressions visible on badly delaminated and thick fragment of rust coating lateral surface. Similar impressions visible on back edge surface (remains of scabbard).

Cat. 14

Knife, reassembled from several smaller fragments (incomplete blade)

Inv. no.: $\mathrm{Z1o} / \mathbf{3}^{2}+\mathrm{Z} 10 / 33+\mathrm{Z} 10 / 34$

Context data: Tumulus 10, burial chamber

Dimensions: $\mathrm{L}=14.6 \mathrm{~cm}$ (after gluing), $\mathrm{W}=2.1 \mathrm{~cm}, \mathrm{Th}=$ $0.5 \mathrm{~cm}$

Material and technique: Forge-welded iron

Description: Single-edged blade with triangular crosssection. Traces of copper oxides on tang represent remains of handle (copper strips provided framework that held scales in place).

\section{Cat. 15}

Iron sleeve fragment with copper oxides (knife part)

Inv. no.: $\mathrm{Z}_{4} / 7.1$

Context data: Tumulus 4 , tunnel

Dimensions: $\mathrm{D}=1.4 \mathrm{~cm}$

Material and technique: Iron with copper coating

Description: Iron sleeve with broken tang wedged inside it. Sleeve covered with copper oxides (remains of copper surface coating). Wood impressions inside.

Cat. 16

Dagger fragment

Inv. no.: $\mathrm{Z}_{4} / 107$

Context data: Tumulus 4 , fill of E tunnel

Dimensions: $\mathrm{L}=5.4 \mathrm{~cm}, \mathrm{~W}=3.4 \mathrm{~cm}, \mathrm{Th}=0.15 \mathrm{~cm}$

Material and technique: Iron

Description: Heavily corroded, broken dagger blade fragment. Double-edged blade, symmetrical with fuller on both sides. Leather impression survives on blade.

\subsection{Arrowheads (Ranged Weapons)}

\section{Cat. 17}

Arrowhead

Inv. no.: $\mathrm{Z1o} / 38$

Context data: Tumulus 10, burial chamber

Dimensions: $\mathrm{L}=6 \mathrm{~cm}, \mathrm{~W}=1.4 \mathrm{~cm}$, cross-section $0.4 \mathrm{~cm}$ 

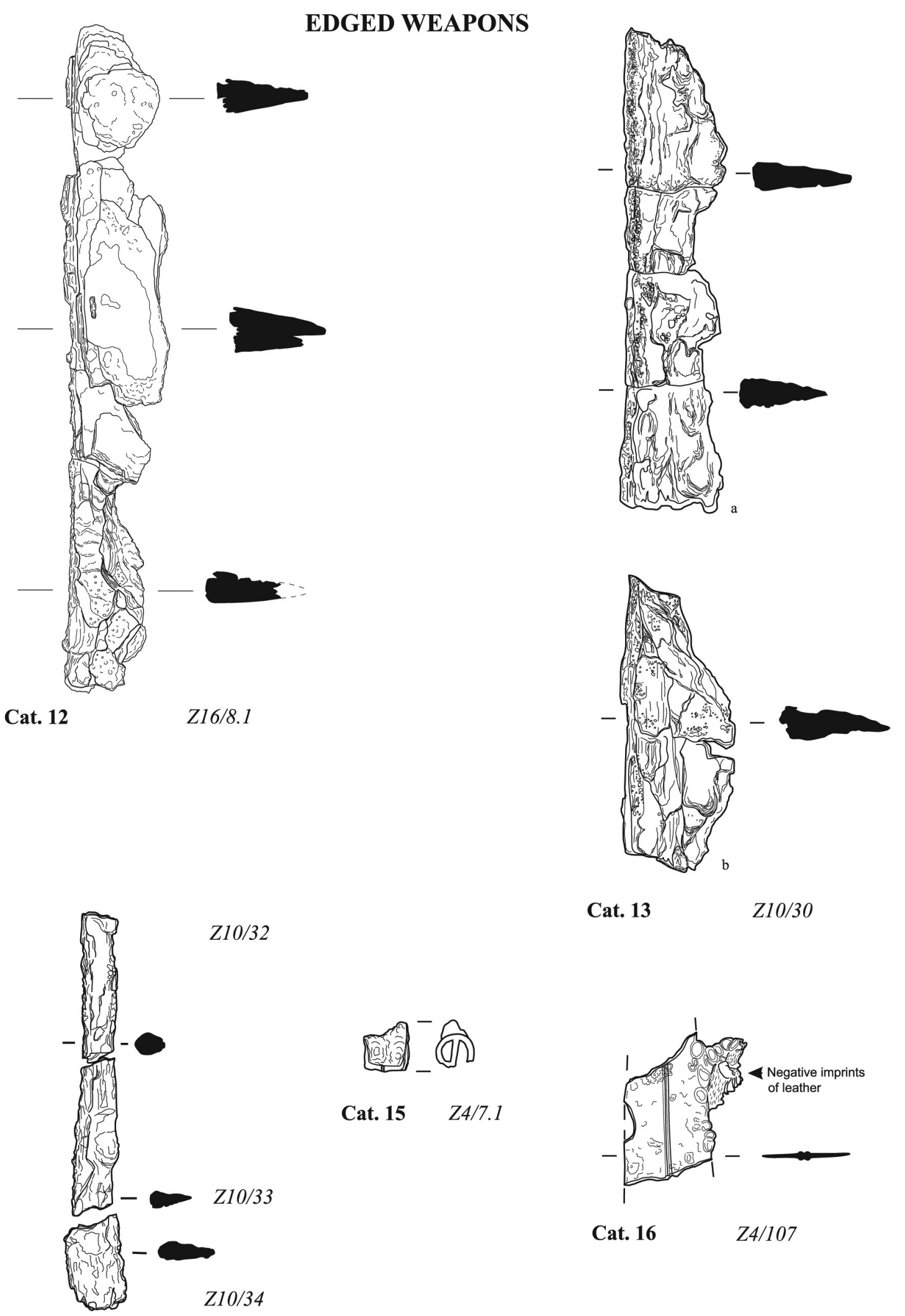

Cat. $13 \quad Z 10 / 30$

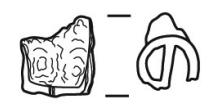

Cat. $15 \quad Z 4 / 7.1$

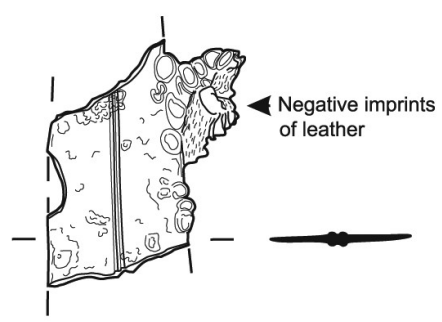

Cat. $16 \quad Z 4 / 107$

Cat. 14

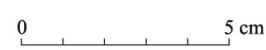

FIGURE 14.4 Edged weapons

Z16/8.1, Z10/30, Z4/7.1, Z4/107 DRAWN AND DIGITISED BY Ł. ZIELIŃSKI;

Z1O/32+Z10/33+Z10/34 DRAWN BY A. BŁASZCZYK, DIGITISED BY Ł. ZIELIŃSKI 
Material and technique: Forged iron

Description: Arrowhead with broken barb, heavily corroded with traces of wood impressions (shaft), type 1.

Cat. 18

Two arrowheads fused together

Inv. no.: $\mathrm{Z} 10 / 39$

Context data: Tumulus 10, burial chamber

Dimensions: a: $\mathrm{L}=6 \mathrm{~cm}, \mathrm{~W}=1.2 \mathrm{~cm}$, cross-section $0.3 \mathrm{~cm}$; b: $\mathrm{L}=6.4 \mathrm{~cm}, \mathrm{~W}=1.4 \mathrm{~cm}$, cross-section $0.3 \mathrm{~cm}$

Material and technique: Forged iron

Description: Two arrowheads fused together, heavily corroded with traces of wood impressions (shaft), probably type 1.

Z21/11 - arrowhead fragments (c. 15 tangs and 8 blades) Context data: Tumulus 21, burial chamber, central part

Dimensions: No more than $2 \mathrm{~cm}$ long

Material and technique: Forged iron

Description: Arrowheads represented by about 15 tangs and 8 blades; two specimens with tip of tang rounded in cross-section giving rise to square-sectioned tang body with lateral notching.

(Cat. 19-28, selected fragments)

Cat. 19

Arrowhead

Inv. no.: $\mathbf{Z 2 1} / \mathbf{1 1 . 2}$

Dimensions: $\mathrm{L}=4.3 \mathrm{~cm}, \mathrm{~W}=1.1 \mathrm{~cm}, \mathrm{Th}=0.35 \mathrm{~cm}$

Description: Iron arrowhead with broken barb, type 1.

Cat. 20

Arrowhead fragment

Inv. no.: Z21/11.9

Dimensions: Preserved L $=4.6 \mathrm{~cm}, \mathrm{~W}=1.2 \mathrm{~cm}, \mathrm{Th}=0.3 \mathrm{~cm}$

Description: Fragment of iron arrowhead with broken point, type 1 .

Cat. 21

Arrowhead

Inv. по.: Z21/11.6

Dimensions: $\mathrm{L}=5.6 \mathrm{~cm}, \mathrm{~W}=1.1 \mathrm{~cm}, \mathrm{Th}=0.3 \mathrm{~cm}$

Description: Complete small iron arrowhead, type 1.

Cat. 22

Arrowhead fragment

Inv. no.: Z21/11.7

Dimensions: Preserved L $=3.2 \mathrm{~cm}, \mathrm{~W}=1.2 \mathrm{~cm}, \mathrm{Th}=0.25 \mathrm{~cm}$

Description: Fragment of small iron arrowhead with broken barb and tang, type 1.
Cat. 23

Inv. no.: Z21/11.11

Dimensions: Preserved L $=3.7 \mathrm{~cm}, \mathrm{~W}=1.1 \mathrm{~cm}, \mathrm{Th}=0.3 \mathrm{~cm}$

Description: Fragment of small iron arrowhead with broken barb and tang, type 1 .

Cat. 24

Arrowhead fragment

Inv. no.: $\mathrm{Z} 21 / 11.8$

Dimensions: Preserved L $=4.9 \mathrm{~cm}, \mathrm{~W}=1.5 \mathrm{~cm}, \mathrm{Th}=0.5 \mathrm{~cm}$

Description: Fragment of elongated blade, clearly larger than other arrowheads in this assemblage. The fragment is difficult to interpret, but is probably a type 1 arrowhead.

Cat. 25

Arrowhead

Inv. no.: Z21/11.12

Dimensions: Preserved L $=2.3 \mathrm{~cm}, \mathrm{~W}=1.1 \mathrm{~cm}, \mathrm{Th}=0.3 \mathrm{~cm}$

Description: Fragment of small iron arrowhead with broken barb and tang, type 1.

Cat. 26

Arrowhead

Inv. no.: Z21/11.13

Dimensions: Preserved L $=1.8 \mathrm{~cm}, \mathrm{~W}=0.9 \mathrm{~cm}, \mathrm{Th}=0.3 \mathrm{~cm}$

Description: Fragment of small iron arrowhead with broken barb and tang, type 1.

Cat. 27

Arrowhead fragment

Inv. no.: Z21/11.4

Dimensions: Preserved L $=2.1 \mathrm{~cm}, \mathrm{~W}=1.1 \mathrm{~cm}, \mathrm{Th}=0.3 \mathrm{~cm}$

Description: Fragment of arrowhead with broken barb and tang, type 1.

Cat. 28

Two fused arrowheads

Inv. no.: $\mathbf{Z} 21 / 11.10$

Dimensions: a: arrowhead 1: $\mathrm{L}=6.3 \mathrm{~cm}, \mathrm{~W}=1.3 \mathrm{~cm}, \mathrm{Th}=$ $0.5 \mathrm{~cm}$; b: arrowhead $2: \mathrm{L}=4 \mathrm{~cm}, \mathrm{~W}=1.2 \mathrm{~cm}, \mathrm{Th}=0.5 \mathrm{~cm}$

Description: Two fragments of arrowheads fused by corrosion, a: with broken tang, type 1 ; b: type 6 .

\section{$\mathrm{Z} 13 / 5$ - group of 30 fragments of arrowheads}

Context data: Tumulus 13, SE part of shaft, near damaged blocking wall

Material and technique: Forged iron

(Cat. 29, selected fragment) 


\section{ARROWHEADS \\ (RANGED WEAPONS)}

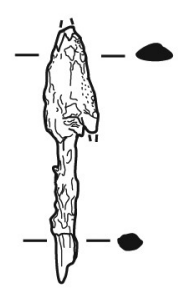

Cat. $17 \quad Z 10 / 38$

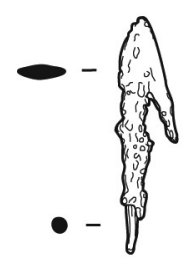

Cat. $21 \quad Z 21 / 11.6$<smiles>C[As]1CC1</smiles>

Cat. $26 \quad Z 21 / 11.13$

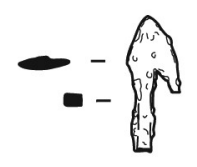

Cat. $22 \quad Z 21 / 11.7$

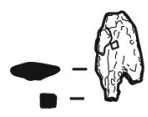

Cat. $27 \quad Z 21 / 11.4$

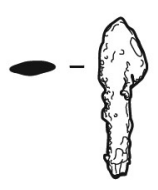

Cat. 23 Z21/11.11

Cat. $24 \quad Z 21 / 11.8$

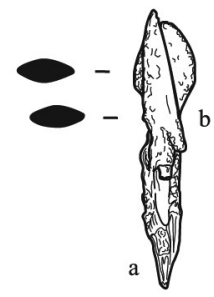

Cat. 28 Z21/11.10

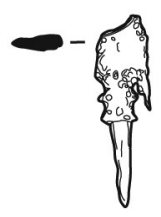

Cat. $20 \quad Z 21 / 11.9$
0 $5 \mathrm{~cm}$
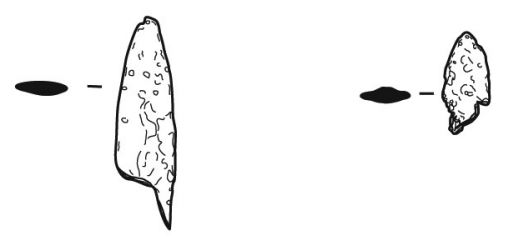

FIGURE 14.5 Ranged weapons: arrowheads

Z10/38, Z10/39, Z13/5.1 DRAWN BY A. BŁASZCZYK, DIGITISED BY Ł. ZIELIŃSKI;

$\mathrm{Z} 21 / 11.2, \mathrm{Z} 21 / 11.9, \mathrm{Z} 21 / 11.6, \mathrm{Z} 21 / 11.7, \mathrm{Z} 21 / 11.11, \mathrm{Z} 21 / 11.8, \mathrm{Z} 21 / 11.12, \mathrm{Z} 21 / 11.13, \mathrm{Z} 21 / 11.4$,

Z21/11.10 DRAWN AND DIGITISED BY Ł. ZIELIŃSKI

Cat. 29

Arrowhead

Inv. no.: $\mathrm{Z13}_{\mathbf{1 3}} \mathbf{5 . 1}$

Dimensions: $\mathrm{L}=6.4 \mathrm{~cm}, \mathrm{~W}=1.15 \mathrm{~cm}, \mathrm{Th}=0.3 \mathrm{~cm}$

Description: Single arrowhead with losses; heavily corroded, type 1.

Cat. 30

Arrowhead

Inv. no.: Z19/7

Context data: Tumulus 19, burial chamber, S part

Dimensions: $\mathrm{W}=1.2 \mathrm{~cm}, \mathrm{Th}=0.3 \mathrm{~cm}$

Material and technique: Forged iron

Description: Complete single-headed arrowhead, heavily corroded; wood impressions on tang, type 1.
Z16/26 - group of 7 fragments of arrowheads

Context data: Tumulus 16, chamber 1, N part near blocking wall

References: Zieliński 2014, 383-384

(Cat. 31-32, selected fragments)

Cat. 31

Two arrowheads (in one lump)

Inv. no.: Z16/26.2, after reattachment of one broken piece Dimensions: $\mathrm{L}=6.2 \mathrm{~cm}, \mathrm{~W}=1.1 \mathrm{~cm}$, blade $\mathrm{Th}=0.2 \mathrm{~cm}$, rectangular tang $0.4 \mathrm{~cm} \times 0.7 \mathrm{~cm}$

Material and technique: Two sides forged from one piece of iron. Typical and simple smithing technique. Lateral surfaces of blade, barb and tang overlap indicating that they were simultaneously worked by the blacksmith.

Description: Single-barbed, sub-triangular arrowheads; 
blade spindle-shaped in cross-section; rectangularsectioned tang. It was possible to clean some surfaces close to the barb and tang, but, overall, both arrowheads are heavily corroded and cracked, type 1 .

\section{Cat. $3^{2}$}

Four arrowheads

Inv. no.: Z16/26.3 (in one lump), three almost complete and one blade fragment

Dimensions: Arrowhead b: $\mathrm{L}=5.8 \mathrm{~cm}$, blade $\mathrm{W}=1.1 \mathrm{~cm}$, blade $\mathrm{Th}=0.1 \mathrm{~cm}$, $\mathrm{Th}=0.4 \mathrm{~cm}$ (on ribs); other arrowheads: $\mathrm{L}=6-6.1 \mathrm{~cm}$

Material and technique: Iron (forged on both sides; blade probably forged and tempered separately and wedged between the forks of the ribs as a continuation of the tang). Unique smithing technique (standard arrowheads of this type are forged from one piece of iron and the blade is spindle-shaped in cross-section).

Description: b: single-barbed, hooked. The blade is a flat lamina, $1 \mathrm{~mm}$ thick, with semicircular ribs on both sides. It was not possible to clean the heavily corroded tang, which is probably rounded in cross-section. The blade was cleaned down to sound metal, revealing traces of smithing under magnification (uncut furrows on the barb and a rectangular chisel mark at the base of the barb, where it joins the tang), type 1 .

Cat. 33

Two fragments, selected from group of five arrowheads

Inv. no.: $\mathrm{Z22} / 7.1+\mathrm{Z22} / 7.2$

Context data: Fill of shaft

Dimensions: a: $\mathrm{L}=3 \mathrm{~cm}, \mathrm{~b}: \mathrm{L}=3 \mathrm{~cm}, \mathrm{Th}=0.9 \mathrm{~cm}$

Material and technique: Forged iron

Description: Five fragments of arrowheads (4 bodies, 1 blade) fused together by corrosion.

Cat. 34

Arrowhead (from assemblage $\mathrm{Z}_{27} / \mathbf{1}$ )

Inv. no.: Z27/1.2

Context data: Tumulus 27, N part of shaft, near burial chamber

Dimensions: $\mathrm{W}=1.3 \mathrm{~cm}, \mathrm{Th}=0.3 \mathrm{~cm}$

Material and technique: Forged iron

Description: Almost complete arrowhead, heavily corroded and broken, type 1 .

Cat. 35

Arrowhead (from assemblage $\mathrm{Z}_{27} / \mathbf{1}$ )

Inv. no.: Z27/1.3

Context data: Tumulus 27, N part of shaft, near burial chamber
Dimensions: $\mathrm{W}=1.3 \mathrm{~cm}, \mathrm{Th}=0.2 \mathrm{~cm}$

Material and technique: Forged iron

Description: Almost complete arrowhead with broken point and barb; heavily corroded and broken, type 1.

Cat. 36

Fifteen arrowhead fragments

Inv. no.: $\mathrm{Z27} / 7$

Context data: Tumulus 27, burial chamber, central part, near skull

Dimensions: Max arrowhead L $=5 \mathrm{~cm}$

Material and technique: Forged iron

Description: Four relatively complete reassembled arrowheads (one type 1 and one type $1 b$ ) and 11 smaller fragments (type $1 \mathrm{~b}$ - one fragment; type 1 - four fragments). Heavily corroded and broken; wood impressions on tangs.

Cat. 37

Broken arrowhead

Inv. no.: $\mathrm{Z}_{4} / \mathbf{2 4}$

Context data: Tumulus 4, Layer 5

Dimensions: $\mathrm{L}=4.2 \mathrm{~cm}$; rectangular-sectioned tang $0.5 \mathrm{~cm}$ $\times 0.4 \mathrm{~cm}$; head: $\mathrm{W}=1.4 \mathrm{~cm}, \mathrm{Th}=0.4 \mathrm{~cm}, \mathrm{~L}=1.8 \mathrm{~cm}$

Material and technique: Forged iron

Description: Broken single-barbed arrowhead, type 1 or 1 .

Cat. 38

Broken arrowhead

Inv. no.: $\mathrm{Z}_{4} / 5^{6}$

Context data: Tumulus $4, \mathrm{~W}$ tunnel

Dimensions: $\mathrm{L}=4.8 \mathrm{~cm}$; square-sectioned tang $0.4 \mathrm{~cm}$; head: $\mathrm{W}=1.1 \mathrm{~cm}, \mathrm{Th}=0.1 \mathrm{~cm}, \mathrm{~L}=1.7 \mathrm{~cm}$

Material and technique: Iron

Description: One broken single-barbed arrowhead, type 1 or 1 .

Cat. 39

Arrowhead

Inv. no.: $\mathrm{Z1o} / 44$

Context data: Tumulus 10, burial chamber

Dimensions: $\mathrm{L}=6.5 \mathrm{~cm}, \mathrm{~W}=1.3 \mathrm{~cm}, \mathrm{Th}=0.3 \mathrm{~cm}, \mathrm{barb}$ $\mathrm{L}=1 \mathrm{~cm}$

Material and technique: Forged iron

Description: Complete single-shot arrowhead, heavily corroded; wood impression on tang, type 1 .

Cat. 40

Broken arrowhead

Inv. no.: $\mathrm{Z}_{4} / \mathbf{2 1 6}$

Context data: Tumulus 4, E tunnel 


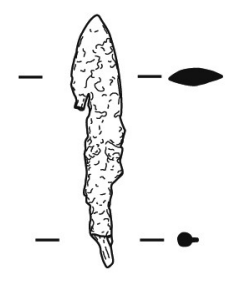

Cat. $30 \quad Z 19 / 7$

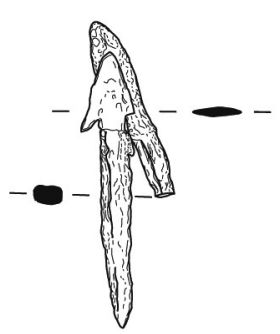

Cat. $31 \quad Z 16 / 26.2$
ARROWHEADS

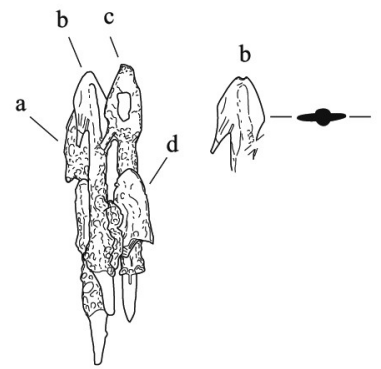

Cat. $32 \quad Z 16 / 26.3$

Cat. $33 Z 22 / 7.1+Z 22 / 7.2$

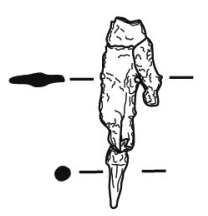

Cat. $34 Z 27 / 1.2$

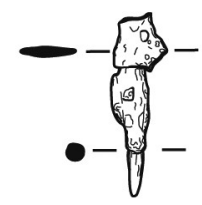

Cat. $35 Z 27 / 1.3$

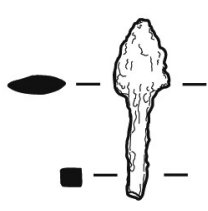

Cat. $37 \quad Z 4 / 24$
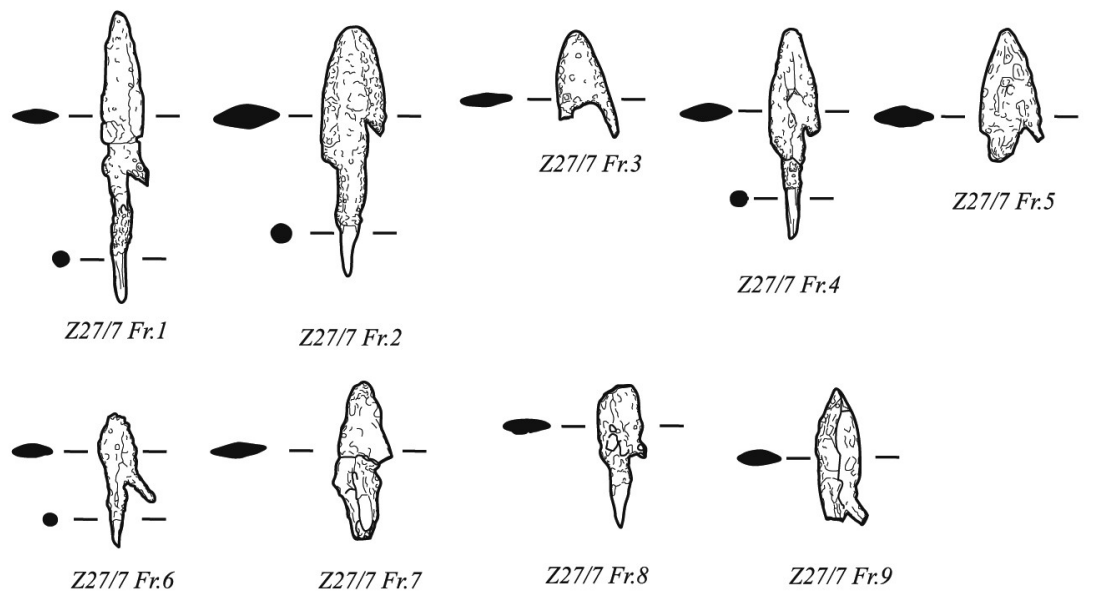

Z27/7 Fr:8

$Z 27 / 7 \mathrm{Fr} .9$

$Z 27 / 7$

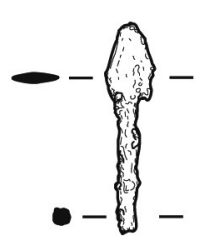

Cat. $38 Z 4 / 56$

Cat. 36

FIGURE 14.6 Ranged weapons: arrowheads

$\mathrm{Z19} / 7, \mathrm{Z16} / 26.2, \mathrm{Z16} / 26.3, \mathrm{Z} 22 / 7.1+\mathrm{Z} 22 / 7.2, \mathrm{Z} 27 / 1.2-3, \mathrm{Z} 27 / 7, \mathrm{Z} 4 / 24, \mathrm{Z} 4 / 56$ DRAWN

AND DIGITISED BY Ł. ZIELIŃSKI

Dimensions: Preserved L $=4.4 \mathrm{~cm}$, square-sectioned tang $0.4 \mathrm{~cm}$; blade: $\mathrm{W}=1 \mathrm{~cm}, \mathrm{Th}=0.25 \mathrm{~cm}$; barb: $\mathrm{L}=0.85 \mathrm{~cm}$ Material and technique: Iron

Description: One broken single-barbed hooked arrowhead, type 1a.

\section{Cat. 41}

Arrowheads fused together (minimum 10 pieces)

Inv. no.: $\mathrm{Z}_{7} / 5$

Context data: Tumulus 17 , burial chamber, $\mathrm{S}$ part

Dimensions: $\mathrm{W}=1.2 \mathrm{~cm}, \mathrm{Th}=0.4 \mathrm{~cm}$

Material and technique: Forged iron

Description: Minimum of 10 fragmented arrowheads fused together. At least four pieces attributable to type 1a. Arrow surfaces covered with distinctive heavy corrosion layer (quiver remnants or human remains). Visible wood impressions on tangs; impressions and fragments of raw hide (probably from a quiver).

Cat. 42

Arrowhead, fragment with broken point Inv. no.: $\mathbf{Z 1 6 / 1 2}$

Context data: Tumulus 16, shaft, near chamber 1

Dimensions: Blade $\mathrm{W}=1.3 \mathrm{~cm}, \mathrm{Th}=0.3 \mathrm{~cm}$, extant length of blade $=3.8 \mathrm{~cm}$, rectangular-sectioned tang $0.4 \mathrm{~cm} \times$ $0.7 \mathrm{~cm}$ 
Material and technique: Forged iron, from one piece (probably simple technique)

Description: Heavily corroded tang fragment with asymmetrical longitudinal blade, broken point and broken barb. Shape and dimensions indicate that this is an elongated variant of a type 1a arrowhead (or less probably type 1 ).

References: Zieliński 2014, 385

\section{Z13/5 - group of 30 fragments of arrowheads}

Context data: Tumulus 13, SE part of shaft, near damaged blocking wall

Material and technique: Forged iron

(Cat. 43-44, selected fragments)

\section{Cat. 43}

Arrowhead

Inv. no.: $\mathrm{Z13} / \mathbf{5 . 2}$

Dimensions: $\mathrm{W}=1 \mathrm{~cm}, \mathrm{Th}=0.4 \mathrm{~cm}$

Description: Single arrowhead with losses; heavily corroded, type $1 b$.

Cat. 44

Arrowhead

Inv. no.: $\mathrm{Z13} / 5 \cdot 3$

Dimensions: $\mathrm{W}=1.2 \mathrm{~cm}, \mathrm{Th}=0.3 \mathrm{~cm}$

Description: Single arrowhead with losses; heavily corroded, type $\mathrm{ib}$.

\section{Cat. 45}

Two arrowheads, two fragments

Inv. no.: $\mathbf{Z 1 6 / 1 1}$

Context data: Tumulus 16 , shaft, central and S part near damaged blocking wall

Dimensions: a: blade $\mathrm{L}=1.4 \mathrm{~cm}, \mathrm{~W}=1.1 \mathrm{~cm}, \mathrm{Th}=0.3 \mathrm{~cm}$; b: blade $\mathrm{L}=1.7 \mathrm{~cm}, \mathrm{~W}=1.1 \mathrm{~cm}, \mathrm{Th}=0.3 \mathrm{~cm}$

Material and technique: Iron forged on both sides, from one piece (simple technique)

Description: Two single-barbed and tanged, leaf-shaped arrowheads, heavily corroded with broken tangs (one completely, one partly). Blade spindle-shaped in crosssection, type $1 b$.

References: Zieliński 2014, 385

\section{Z16/26 - group of 7 arrowhead fragments}

Context data: Tumulus 16, chamber 1, N part near blocking wall

References: Zieliński 2014, 383-384

(Cat. 46, selected fragment)

\section{Cat. 46}

Arrowhead

Inv. no.: Z16/26.1, reassembled (almost complete)

Dimensions: $\mathrm{Max} \mathrm{W}=1 \mathrm{~cm}, \mathrm{Th}=0.1 \mathrm{~cm}$, square-sectioned barb $0.2 \mathrm{~cm}$, oval-sectioned tang $0.4 \mathrm{~cm} \times 0.3 \mathrm{~cm}$

Material and technique: Iron forged from one side from one piece, other side flat (uncommon smithing technique)

Description: Leaf-shaped, single-barbed arrowhead with tang; typical post-Meroitic form (type $1 \mathrm{~b}$, short variant). One side completely flat; barb and tang on other side. Light surface cleaning revealed sound metal (traces of smithing visible near barb under magnification).

Z21/11-arrowhead fragments (c. 15 mandrels/tangs and 8 blades)

Context data: Tumulus 21, burial chamber, central part

Dimensions: No more than $2 \mathrm{~cm}$ long

Material and technique: Forged iron

Description: Arrowheads represented by about 15 tangs and 8 blades; two specimens with tip of tang rounded in cross-section giving rise to square-sectioned tang body with lateral notching.

(Cat. 47-49, selected fragments)

\section{Cat. 47}

Arrowhead fragment

Inv. no.: Z21/11.3

Dimensions: Preserved L $=2.4 \mathrm{~cm}, \mathrm{~W}=1.1 \mathrm{~cm}, \mathrm{Th}=0.3 \mathrm{~cm}$

Description: Fragment of arrowhead blade with broken tang, type $1 b$.

Cat. 48

Arrowhead

Inv. no.: Z21/11.1

Dimensions: Preserved L $=4 \mathrm{~cm}$, cross-section $0.45 \mathrm{~cm}$

Description: Fragment of arrowhead tang, square in section with characteristic notching (surface of tip very well preserved).

\section{Cat. 49}

Arrowhead fragment

Inv. no.: $\mathrm{Z}_{21} / \mathbf{1 1 . 5}$

Dimensions: Preserved L $=2.1 \mathrm{~cm}$, cross-section $0.4 \mathrm{~cm} \times$ $0.4 \mathrm{~cm}$

Description: Fragment of arrowhead tang, square in section with characteristic notching (surface of tip very well preserved).

Cat. $5^{\circ}$

Arrowhead (from assemblage Z27/1)

Inv. no.: $\mathrm{Z}_{27} / \mathbf{1 . 1}$ 


\section{ARROWHEADS}

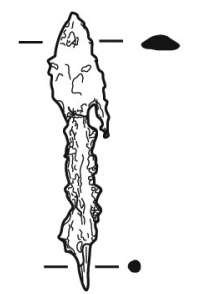

Cat. $39 \quad Z 10 / 44$

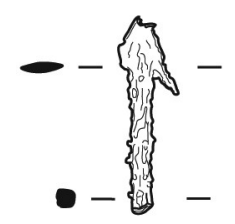

Cat. $40 \quad Z 4 / 216$

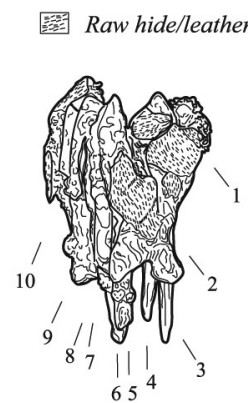

Cat. $41 Z 17 / 5$

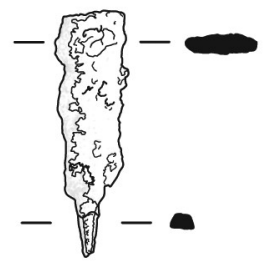

Cat. $42 \quad Z 16 / 12$

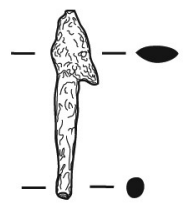

Cat. $43 \quad Z 13 / 5.2$

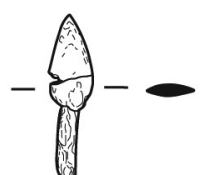

Cat. $44 Z 13 / 5.3$

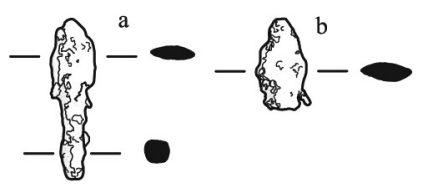

Cat. 45
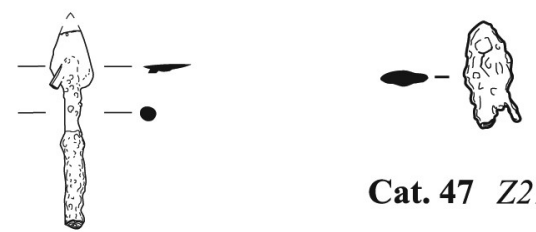

Cat. 47 Z21/11.3

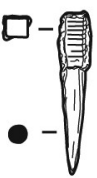

Cat. 48 Z21/11.1

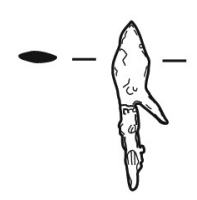

Cat. $50 \quad Z 27 / 1.1$

Cat. $46 \quad Z 16 / 26.1$

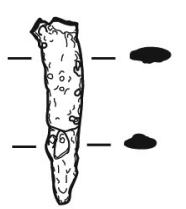

Cat. $51 \quad Z 27 / 1.4$

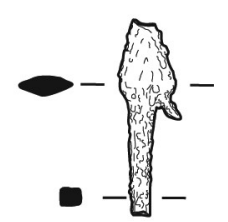

Cat. $52 \quad Z 4 / 87$

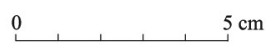

FIGURE 14.7 Ranged weapons: arrowheads Z1O/44, Z13/5.2, Z13/5.3 DRAWN BY A. BŁASZCZYK, DIGITISED BY Ł. ZIELIŃSKI; Z4/216, Z16/26.1, Z21/11.3, Z21/11.1, Z21/11.5, Z27/1.1, Z27/1.4, Z4/87 DRAWN AND DIGITISED BY Ł. ZIELIŃSKI; Z17/5 DRAWN BY K. JUSZCZYK, DIGITISED BY E. CZYŻEWSKA-ZALEWSKA; Z16/11, Z16/12 DRAWN BY K. JUSZCZYK, DIGITISED BY U. IWASZCZUK

Context data: Tumulus 27, N part of shaft, near burial chamber

Dimensions: $\mathrm{L}=3.7 \mathrm{~cm}, \mathrm{~W}=0.9 \mathrm{~cm}, \mathrm{Th}=0.25 \mathrm{~cm}$, blade $\mathrm{L}=2 \mathrm{~cm}$

Material and technique: Forged iron

Description: Almost complete arrowhead (type $1 \mathrm{~b}$ ); heavily corroded and broken.

\section{Cat. 51}

Arrowhead fragment (from assemblage Z27/1)

Inv. no.: Z27/1.4

Context data: Tumulus 27, N part of shaft, near burial chamber
Dimensions: $\mathrm{W}=0.9 \mathrm{~cm}, \mathrm{Th}=0.4 \mathrm{~cm}$, blade $\mathrm{L}=c .4 .4 \mathrm{~cm}$ Material and technique: Forged iron

Description: Fragment of arrowhead (reassembled from fragments catalogued under Z27/1), heavily corroded and broken, type $1 \mathrm{~b}$, elongated version.

Cat. $5^{2}$

Broken arrowhead

Inv. no.: $\mathrm{Z}_{4} / 87$

Context data: Tumulus 4, W tunnel

Dimensions: Preserved L $=4.5 \mathrm{~cm}$; square-sectioned tang: $0.4 \mathrm{~cm}$, blade: $\mathrm{L}=2 \mathrm{~cm}, \mathrm{~W}=1.3 \mathrm{~cm}, \mathrm{Th}=0.5 \mathrm{~cm}$ (original $\mathrm{Th}=0.2 \mathrm{~cm})$, barb: $\mathrm{L}=0.6 \mathrm{~cm}$ 
Material and technique: Forged iron

Description: Broken single-barbed leaf-shaped arrowhead, type $1 \mathrm{~b}$.

\section{Cat. 53}

Three fused arrowhead blades (from assemblage Z27/1)

Inv. no.: Z27/1.5

Context data: Tumulus 27, N part of shaft, near burial chamber

Dimensions: $\mathrm{W}=1.1 \mathrm{~cm}, \mathrm{Th}=0.35 \mathrm{~cm}$, blade $\mathrm{L}=c .3 \mathrm{~cm}$

Material and technique: Forged iron

Description: Three fragments of arrowhead fused together by corrosion, heavily corroded and broken, only blades_-one attributable to type $1 \mathrm{~b}$.

\section{Cat. 54}

Two broken arrowheads

Inv. no.: $\mathrm{Z}_{4} / 88$

Context data: Tumulus $4, \mathrm{~W}$ tunnel

Dimensions: a: preserved $\mathrm{L}=5.2 \mathrm{~cm}$, rectangular tang $0.4 \mathrm{~cm} \times 0.5 \mathrm{~cm}$, blade: $\mathrm{L}=1.8 \mathrm{~cm}, \mathrm{~W}=1.3 \mathrm{~cm}, \mathrm{Th}=0.4 \mathrm{~cm}$ (original Th $=0.2 \mathrm{~cm}$ ); b: preserved $\mathrm{L}=3.2 \mathrm{~cm}$, roundsectioned tang $0.4 \mathrm{~cm} \times 0.4 \mathrm{~cm}, \mathrm{~W}=1.4 \mathrm{~cm}$; broken blade: original $\mathrm{Th}=0.2 \mathrm{~cm}$, barb: preserved $\mathrm{L}=0.2 \mathrm{~cm}$

Material and technique: Forged iron

Description: Two broken arrowheads fused together by corrosion; single-barbed leaf-shaped; extant hide impression (representing quiver), both type $1 \mathrm{~b}$.

Cat. 55

Arrowhead

Inv. no.: $\mathbf{Z 1 o} / 37$

Context data: Tumulus 10, burial chamber

Dimensions: $\mathrm{L}=5 \mathrm{~cm}, \mathrm{~W}=1.1 \mathrm{~cm}$, cross-section $0.5 \mathrm{~cm}$

Material and technique: Forged iron

Description: Heavily corroded with traces of wood impression (shaft), type 6 .

Cat. 56

Three arrowheads fused together

Inv. no.: $\mathbf{Z 1 0} / 47$

Context data: Tumulus 10, burial chamber

Dimensions: $\mathrm{L}=5.5 \mathrm{~cm}, \mathrm{~W}=1.2 \mathrm{~cm}$, Th $=0.4 \mathrm{~cm}$

Material and technique: Forged iron

Description: Three arrowheads, fused together by corrosion; heavily corroded; wood impressions on tangs, type 6 .

Cat. 57

Arrowhead fragment

Inv. no.: Z1o/41

Context data: Tumulus 10, burial chamber
Dimensions: Preserved L $=3.8 \mathrm{~cm}$, cross-section $0.5 \mathrm{~cm}$

Material and technique: Forged iron

Description: Arrowhead tang (probably single-barbed), heavily corroded.

\section{Cat. 58}

Arrowhead fragment

Inv. no.: $\mathrm{Z1O} / 42$

Context data: Tumulus 10, burial chamber

Dimensions: $\mathrm{L}=2.5 \mathrm{~cm}$, cross-section $0.5 \mathrm{~cm}$

Material and technique: Forged iron

Description: Arrowhead tang, heavily corroded.

Cat. 59

Arrowhead fragment

Inv. no.: Z1o/43

Context data: Tumulus 10, burial chamber

Dimensions: $\mathrm{L}=4.8 \mathrm{~cm}$, cross-section $0.5 \mathrm{~cm}$

Material and technique: Forged iron

Description: Asymmetrical arrowhead tang (probably single-barbed).

Cat. 6o

Three fused arrowhead fragments

Inv. no:: $\mathbf{Z 1 o} / 48$

Context data: Tumulus 10, burial chamber

Dimensions: $\mathrm{L}=3.5 \mathrm{~cm}$, cross-section $0.5 \mathrm{~cm}$

Material and technique: Forged iron

Description: Three broken arrowheads fused together by corrosion (type unrecognizable).

Cat. 61

Three fused fragments of arrowheads (1 tang, 2 blades)

Inv. no.: $\mathrm{Z1O} / 49$

Context data: Tumulus 10, burial chamber

Dimensions: Cross-section $0.5 \mathrm{~cm}$ (tang), $\mathrm{Th}=0.3 \mathrm{~cm}$

Material and technique: Forged iron

Description: Three fragments of arrowheads fused together (1 tang, 2 blades); heavily corroded and broken.

Cat. 62

Four fragments of arrowheads fused together

Inv. no.: $\mathrm{Z} 10 / 53$

Context data: Tumulus 10, burial chamber

Dimensions: $\mathrm{W}=1-1.2 \mathrm{~cm}, \mathrm{Th}=0.3 \mathrm{~cm}$

Material and technique: Forged iron

Description: Four fragments of arrowheads fused together; heavily corroded and broken.

Cat. 63

Two arrowhead fragments

Inv. no.: $\mathrm{Z17} / 12$ 
WEAPONRY AND MILITARY EQUIPMENT

99

ARROWHEADS

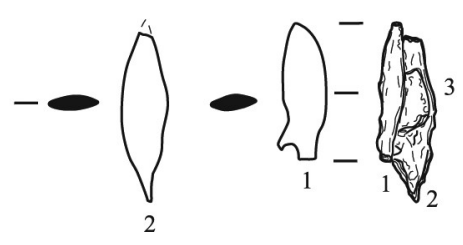

Cat. 53

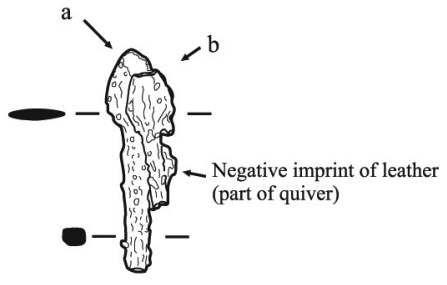

Cat. 54

Z4/88

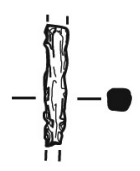

Cat. 58 Z10/42

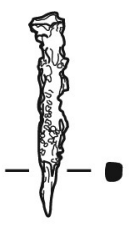

Cat. 59 Z10/43

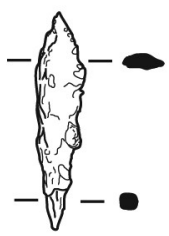

Cat. $55 \quad Z 10 / 37$

Cat. $56 \quad Z 10 / 47$

Cat. 57 Z10/41

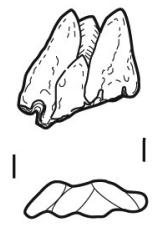

Cat. $62 \quad Z 10 / 53$

Cat. 63 Z17/12

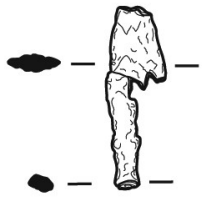

Cat. $67 \quad Z 27 / 10$

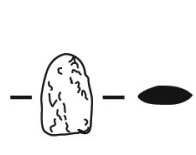

Cat. 65

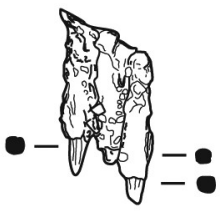

Cat. $60 \quad Z 10 / 48$

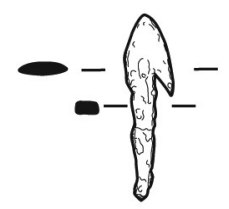

Cat. $66 \quad Z 21 / 13$
Cat. $64 \quad Z 16 / 27$
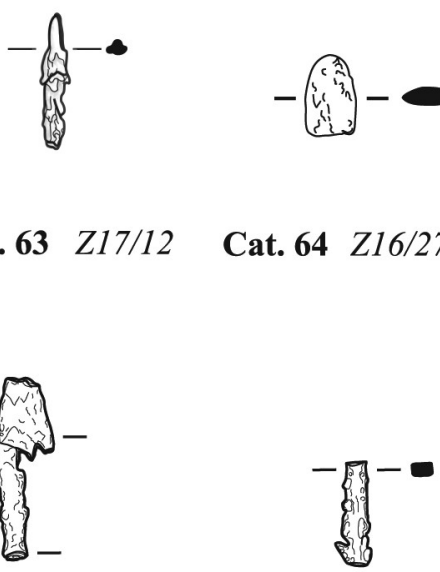

Cat. $68 \quad Z 4 / 28$

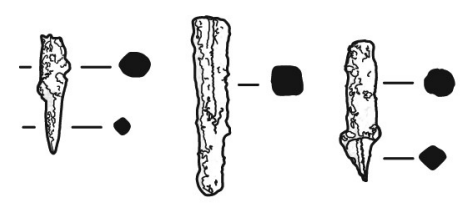

Z16/10

FIGURE 14.8 Ranged weapons: arrowheads Z27/1.5, Z4/88, Z21/13, Z27/10, Z4/28 DRAWN AND DIGITISED BY Ł. ZIELIŃSKI; $\mathrm{Z1O} / 37, \mathrm{Z1O} / 47, \mathrm{Z1O} / 41, \mathrm{Z1O} / 42, \mathrm{Z1O} / 43, \mathrm{Z1O} / 48, \mathrm{Z1O} / 49, \mathrm{Z1O} / 53$ DRAWN BY A. BŁASZCZYK, DIGITISED BY Ł. ZIELIŃSKI; Z17/12 DRAWN BY K. JUSZCZYK, DIGITISED BY E. CZYŻEWSKA-ZALEWSKA; Z16/27 DRAWN BY K. JUSZCZYK, DIGITISED BY Ł. ZIELIŃSKI; Z16/1O DRAWN BY K. JUSZCZYK, DIGITISED BY U. IWASZCZUK

Łukasz Zieliński - 9789004433755

Downloaded from Brill.com@4/26/2023 $07: 58: 06 \mathrm{AM}$
via free access 
Context data: Tumulus 17, burial chamber, S part

Dimensions: Cross-section $0.4 \mathrm{~cm}$

Material and technique: Forged iron

Description: Two heavily corroded fragments of arrowhead tang (type unrecognizable).

\section{Cat. 64}

Arrowhead, blade fragment

Inv. no.: Z16/27

Context data: Tumulus 16, chamber 1, part N, near vessel $\mathrm{Zi} 6 / 3$

Dimensions: Blade $\mathrm{W}=1.2 \mathrm{~cm}, \mathrm{Th}=0.3 \mathrm{~cm}$

Material and technique: Forged iron

Description: Broken fragment of arrowhead blade (point only), with spindle-shaped cross-section and heavily corroded surface. Poor diagnostic piece (dimensions and shape suggest a post-Meroitic arrowhead, probably a single-barbed one).

References: Zieliński 2014, 384

\section{Cat. 65}

Arrowheads, 14 fragments (11 tang fragments, 3 other fragments)

Inv. no.: Z16/10

Context data: Tumulus 16 , shaft, central and S part near damaged blocking wall

Dimensions: Tang fragments no longer than $3-3.5 \mathrm{~cm}$

Material and technique: Forged iron

Description: Heavily corroded tangs and other indeterminate iron splinters from arrowheads.

References: Zieliński 2014, 385

Cat. 66

Arrowhead

Inv. no.: Z21/13

Context data: Tumulus 21, burial chamber, $\mathrm{N}$ part, near beads

Dimensions: $\mathrm{L}=4.3 \mathrm{~cm}, \mathrm{~W}=1.1 \mathrm{~cm}, \mathrm{Th}=0.25 \mathrm{~cm}$

Material and technique: Forged iron

Description: Small iron arrowhead reassembled from two fragments (asymmetrical, single-barbed).

Cat. 67

Group of nine arrowhead fragments

Inv. no.: Z27/10

Context data: Tumulus $27, \mathrm{~N}$ part of shaft, near burial chamber

Dimensions: Largest fragment $\mathrm{L}=4.7 \mathrm{~cm}$

Material and technique: Forged iron

Description: Eleven different fragments: three definite fragments of arrowheads (two blade fragments, one broken barb), one long fragment, bent and broken at the end $(\mathrm{L}=4.7 \mathrm{~cm}$ ), seven other fragments (two possible fragments of arrowheads). Heavily corroded and broken.

\section{Cat. 68}

Arrowhead tang fragment

Inv. no.: $\mathbf{Z}_{\mathbf{4}} / \mathbf{2 8}$

Context data: Tumulus 4, Layer 5

Dimensions: Preserved $\mathrm{L}=2.4 \mathrm{~cm}$, rounded cross-section $0.4 \mathrm{~cm} \times 0.4 \mathrm{~cm}$

Material and technique: Forged iron

Description: One arrowhead tang fragment.

\subsection{Thumb Rings (Ranged Weapons)}

\section{Cat. 69}

Thumb ring (archer's loose)

Inv. no.: $\mathrm{Z} 7 / 3$

Context data: Tumulus 7 , context 5

Dimensions: Inside D $=2 \mathrm{~cm}$, constriction in middle 1.85 $\mathrm{cm}$; outside $\mathrm{D}=3 \mathrm{~cm}$ (top), $5 \mathrm{~cm}$ (bottom), $\mathrm{H}=4.7 \mathrm{~cm}$

Material and technique: Stone-porphyry

Description: Outer surface bleached and smooth; longitudinal scratches evidencing processing (sawing) visible on inner surface. Very nicely worked (almost straight edges and even surfaces), Emery type 2.

Cat. 70

Thumb ring (archer's loose)

Inv. no.: $\mathrm{Z}_{7} / 2$

Context data: Tumulus 7 , context 5

Dimensions: Inside D $=2.1 \mathrm{~cm}$; outside D $=2.8 \mathrm{~cm}$ (top), $4.6 \mathrm{~cm}$ (bottom); $\mathrm{H}=4.4 \mathrm{~cm}$

Material and technique: Stone-feldspathic sandstone

Description: Nicely worked (almost straight edges and even surfaces); quite porous surfaces (no polishing). Longitudinal scratches evidencing processing (sawing) visible on inner surface. Broken ring (approximately halfextant) with crack at base, Emery type 4 .

\section{Cat. 71}

Thumb ring (archer's loose)

Inv. no.: $\mathrm{Z}_{7} / 4$

Context data: Tumulus 7 , context 5

Dimensions: Inside D $=2.15 \mathrm{~cm}$; outside D $=2.9 \mathrm{~cm}$ (top), $4.8 \mathrm{~cm}$ (bottom), $\mathrm{H}=4.2 \mathrm{~cm}$

Material and technique: Stone-feldspathic sandstone (ferriferous)

Description: Nicely worked (almost straight edges and even surfaces), quite porous surfaces (no polishing). Longitudinal scratches evidencing processing (sawing) visible on inner surface. Lateral surface features roughly 


\section{THUMB-RING}

(RANGED WEAPONS)

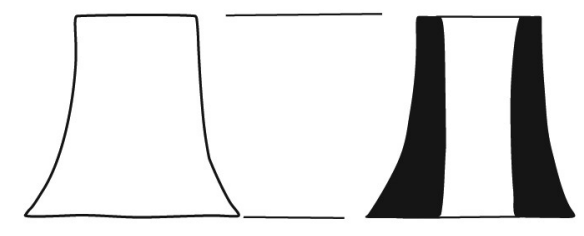

Cat. 69

$Z 7 / 3$

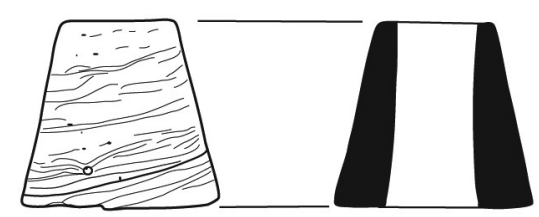

Cat. 70

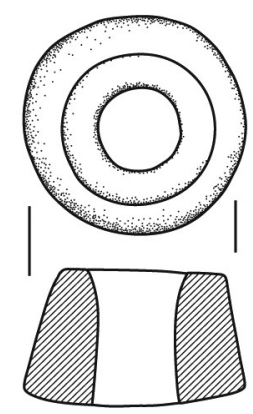

Cat. 72
$Z 24 / 6$

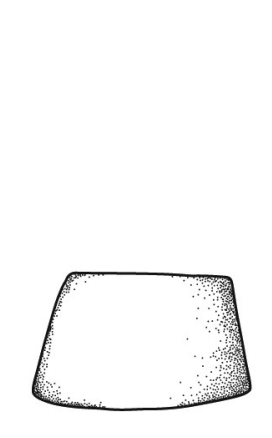

$Z 7 / 2$

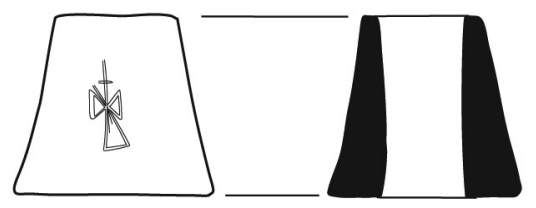

Cat. 71 $Z 7 / 4$

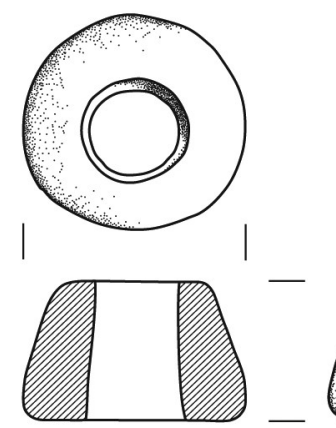

Cat. 73 $5 \mathrm{~cm}$

FIGURE 14.9 Archer's looses/thumb rings

$\mathrm{Z}_{7} / 3, \mathrm{Z} 7 / 2, \mathrm{z} 7 / 4, \mathrm{Z} 24 / 6, \mathrm{Z27} / 6$ DRAWN BY Ł. ZIELIŃSKI, DIGITISED BY E. CZYŻEWSKA-ZALEWSKA

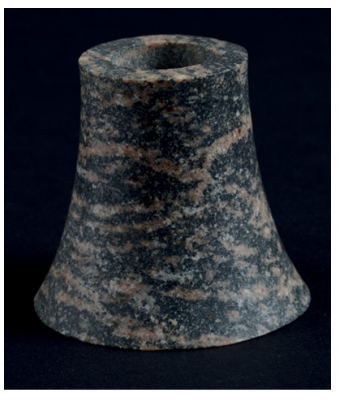

Cat. 69

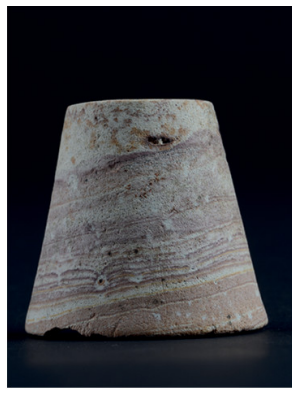

Cat. 70

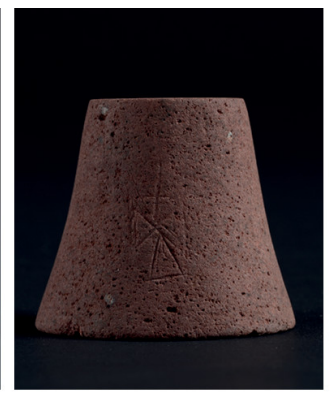

Cat. 71

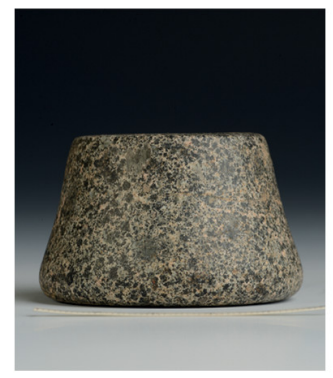

Cat. 72

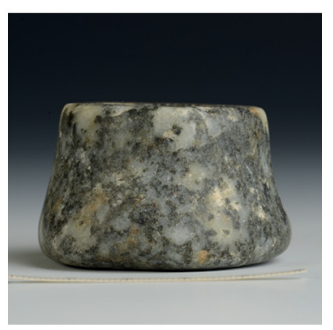

Z24/6 Cat. 73

$Z 27 / 6$

$2 \mathrm{~cm}$

FIGURE 14.10 Archer's looses discovered in El-Zuma tumuli PHOTOS BY A. KAMROWSKI 
scratched cross with flared arms (top arm least carefully executed), Emery type 4.

Cat. 72

Thumb ring (archer's loose)

Inv. no.: $\mathbf{Z}_{24} / 6$

Context data: Tumulus 24, SE part of shaft, fill

Dimensions: Inside D $=2.2 \mathrm{~cm}$, constriction in middle $1.75 \mathrm{~cm}$; outside D = $3.9 \mathrm{~cm}$ (top), $5 \mathrm{~cm}$ (bottom); $\mathrm{H}=$ $3.1 \mathrm{~cm}$ (weight: 119-120g)

Material and technique: Stone-diorite

Description: Outer surface smooth but scratched; inner surface smooth from use. Two splinters on upper edge; bottom surface uneven with one loss and edges more rounded than those of top surface, Emery type 8.

Cat. 73

Thumb ring (archer's loose)

Inv. no.: $\mathrm{Z}_{27} / 6$

Context data: Tumulus 27, burial chamber, central part, near skull

Dimensions: Inside $\mathrm{D}=2.2 \mathrm{~cm}$, constriction in middle $1.9 \mathrm{~cm}$; outside $\mathrm{D}=3.7 \mathrm{~cm}$ (top), $5.1 \mathrm{~cm}$ (bottom), $\mathrm{H}=$ $3.27 \mathrm{~cm}$ (weight: 120-121 g)

Material and technique: Stone-granite

Description: Outer surface smooth but scratched; inner surface smooth and shiny from use. Very nicely worked (almost straight edges and even surfaces), slightly uneven base with faint scratches. Longitudinal scratch on lateral surface. One small loss to top edge, Emery type 8 . 